\title{
The nature of scour development and scour protection at offshore windfarm foundations
}

\author{
Richard JS Whitehouse ${ }^{1}$, John M Harris ${ }^{1,(\text { Previously 2), }}$ \\ James Sutherland ${ }^{1}$ and Jon Rees ${ }^{3}$
}

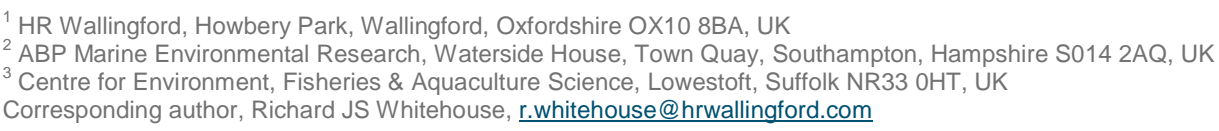

Published in Marine Pollution Bulletin, Volume 62, Issue 1, January 2011, pp73-88

\section{Abstract}

Analysis and interpretation of monitoring data for the seabed bathymetry local to offshore windfarm foundations has shown how the scour develops in time and highlighted variations between sites with different seabed sediment characteristics, i.e. sands and clays. Results from European offshore windfarms have generated a unique dataset for comparison with previously published data. Where surficial sediment is underlain by a marine clay the scour (to date) has been limited, whilst those with unconstrained depths of sandy sediments show scour as deep as 1.38 times the monopile diameter. Scour protection has been installed at some sites for structural stability of the foundation or for cable protection. The flow interaction with the protection causes edge scour or secondary scour in the seabed around the protection. In some cases this scour is deeper than the unprotected case. The analysis has resulted in an improved evidence base for scour in the marine environment.

\section{Keywords}

foundations, monopile, offshore, windfarm, scour, scour protection

\section{Introduction}

The expansion of renewable energy generating capacity offshore has led to the opportunity to assess the physical impact of wind turbine foundation structures on the seabed by analysis of monitoring data. At the planning stage projects are required to determine the physical impact on the seabed arising from installed structures as part of the environmental studies informing the application for a generating licence. For a complete understanding of the seabed level variation over the design life of the windfarm considerations arise, firstly, with respect to regional changes due to migration of seabed features such as sandbanks, sandwaves or channels as well as, secondly, local scour around the turbine foundations and any scour protection that has been placed. This paper deals with the second of these topics.

The present day rate of seabed erosion, sediment transport and movement of bed features are controlled over time periods of weeks-month-years-decades by the variations in tidal range, manifest by way of 
currents, storm surges and wave action (Stride, 1982). The current distribution of sediments on the continental shelf reflects the balance between the supply of different grades of sediment (clay-silt-sandgravel) and the reworking over millennia by the prevailing hydrodynamic conditions. When a wind turbine foundation is installed the hydrodynamic field will be increased locally (Whitehouse, 1998) producing an associated increase in sediment transport and erosion. The local physical impact of this increase will be scouring of the seabed around the foundation which, depending on conditions, will be large or small in depth and lateral extent. Despite research over many years, particularly in the offshore oil and gas industry, there is still a high level of uncertainty as to the potential depth of scour in relation to offshore wind turbine foundations and, therefore, uncertainty as to the need for scour protection. A conceptual model of the scour depth development around marine foundations which is applicable to wind turbine foundations was presented by Whitehouse (2006) (Figure 1). This indicates how scour might be expected to develop under normal (i.e. non-extreme) prevailing conditions and under extreme (i.e. annual storm) conditions. The model will be discussed later in the paper.

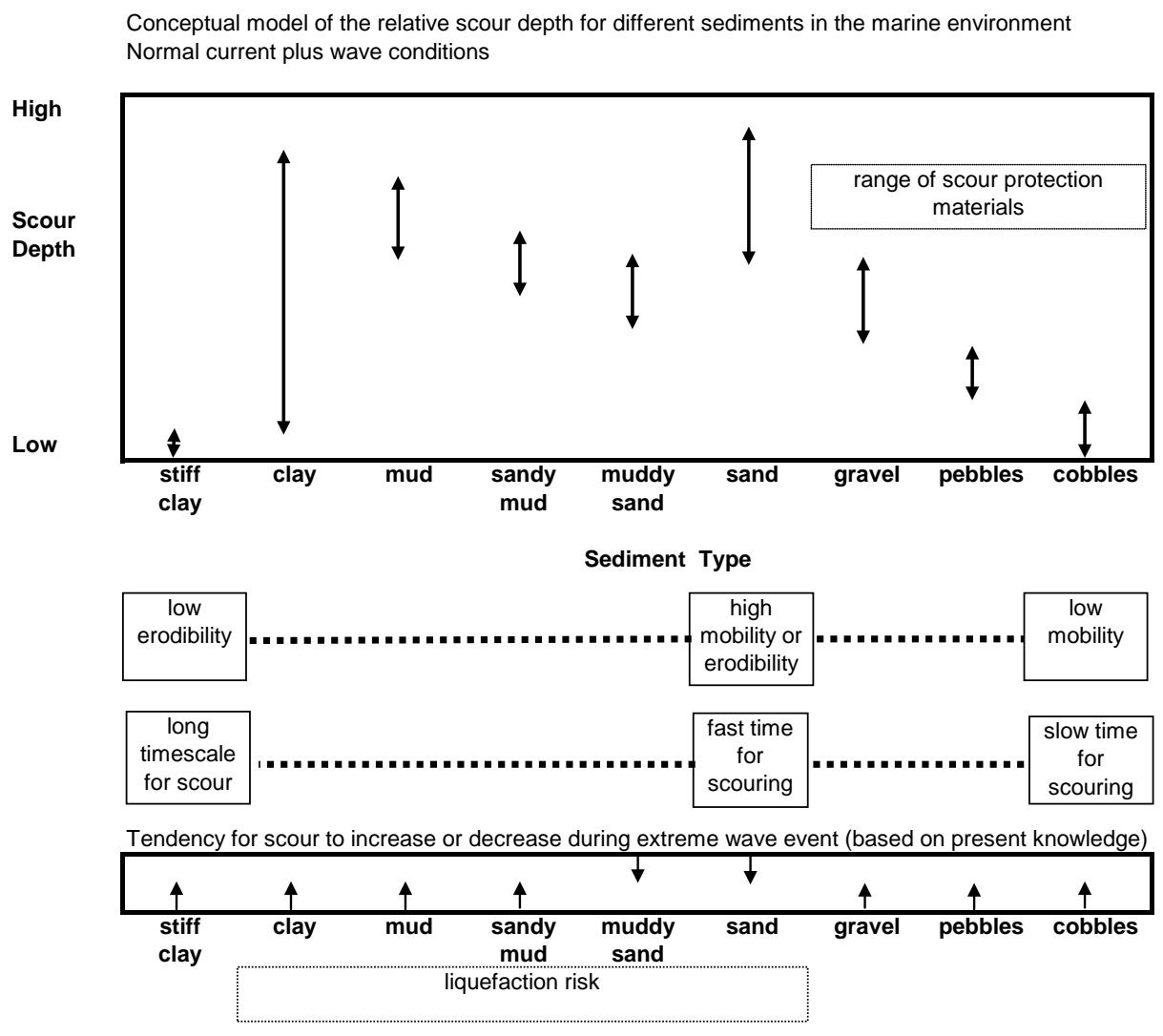

Figure 1: Conceptual model for scour development around marine foundations (modified from Whitehouse, 2006)

Scour around marine structures is well recognised as an engineering issue. Where scour is anticipated to cause problems of structural stability scour protection is required (Hoffmans and Verheij, 1997; Whitehouse, 1998; Sumer and Fredsøe, 2002). Scour protection may be required also to safeguard the cables that run between turbines where they pass from being buried under the seabed up into the transition piece on the foundation. Where the seabed previously consisted of relatively uniform sand and scour protection is needed there is likely to be an increase in the habitat diversity due to the introduction of a new substratum on the seabed. Use of scour protection may result in physical impacts on seabed morphology, sediments, 
fisheries and navigation. The placement of the scour protection at Scroby Sands off the east coast of England, for example, has led to extensive secondary scour around the scour protection, which has been noted as an unintended consequence (CEFAS, 2006). Whether the introduction of these new habitats is a positive benefit is dependent on the assessment criteria used. Wilson and Elliott (2009) suggest that using current design criteria and construction methods for monopile foundations the net amount of habitat created is up to 2.5 times the amount of area lost through the placement. They suggest there is evidence of net gain in habitat although the nature of the gain may be different from the habitat lost. Whilst the formation of artificial reefs may be beneficial at an individual structure level there may be beneficial group effects from the network of reefs and the windfarm may act as a sanctuary area for threatened or vulnerable species. Linley et al (2007) outlined the potential benefits of turbine towers and associated scour protection to colonization, recovery or curation of species. They also discussed the considerations associated with the closure of Offshore Wind Farm (OWF) footprints as part of a wider strategic approach to partial or full 'no-take' Marine Protected Areas.

Within the UK all offshore wind farms constructed to date have made use of monopile foundations, however, a different foundation design (e.g. a gravity base structure or multi-legged steel jacket structure) may lead to different impacts on benthic habitats. For a review of the different foundation solutions see Byrne and Houlsby (2003). Gravity base foundations generally require substantial seabed preparations and where scour protection is installed below the level of the surrounding seabed there is the potential for sediment accretion changing what are potential hard substrates to silty/sandy seabeds and the possible accumulation of decaying macro-algae and the development of elevated nutrient levels. Therefore, the effects of sediment smothering, sediment accretion and scouring may lead to a corresponding reduction in benthic recruitment success, etc.

The aim of the current paper is to evaluate the development of scour on the seabed from an analysis of monitoring results of data from built offshore windfarms, supplemented with reference to other published datasets. The sensitivity of a range of different seabed sediment environments to the physical process of scour is assessed. Knowledge of the scour that has developed to date around offshore windfarm foundations supplements the existing guidance available from Det Norske Veritas (DNV) (2007) and is also informative for other offshore renewable technologies.

\subsection{Sensitivity of seabed to scour}

An updated version of the conceptual model for scour sensitivity over the full range of marine sediment types prepared by Whitehouse (2006) is shown in Figure 1. This is indicative having been based on pre-existing knowledge and judgment and requires quantification in terms of scour at specific structures. The conceptual model takes sand as the benchmark case for scour, the sediment type for which most is known, and in general terms scour is expected to decrease for both coarser and finer soils as the susceptibility to erosion reduces, although muds and clays may be quite variable in their response depending on their formation history and degree of compaction. Where cyclic loading by waves leads to pore pressure build up in the soil there is a possibility for wave-induced liquefaction to occur in which the effective stress of the soil is reduced, i.e. it has reduced strength. The range of soils subject to liquefaction is indicated in Figure 1 and whilst liquefaction is not considered further in the present paper more details can be found in Sumer (2006). The resistance to scour provided by clay in the marine environment needs further investigation. Clay with undrained shear strength of order $100 \mathrm{kPa}$ is probably resistant to scouring in open sea environments although Jiang et al. (2004) observed a scour depth of $5 \mathrm{~m}$ in firm clay adjacent to an oil-unloading terminal in a tidal river; therefore, in some environments it is necessary to treat stiff clay as a scour hazard. Seabed 
sediments at the coarse end of the sediment range exhibit higher resistance to movement and are akin to the materials placed in sandy environments as scour protection.

For some sediments it is expected that the depth of scouring will increase with increased hydraulic forcing associated with storm waves, whilst in other sediments waves may actually lead to a decrease in the scour depth (indicated in the lower part of Figure 1). Where events with high enough energy for erosion occur frequently enough or are long enough in duration the rate of scour will increase with higher energy levels. However, in a time-limited event such as a storm the scour response of the seabed will depend on the sensitivity of the seabed to increased shearing force on the seabed, and the severity of the event.

Assessing scour in multimodal mixtures of sands, silts and clays continues to be a challenge due to the spatial, vertical and temporal variation in soil conditions. It may be possible to develop site specific relationships between undrained shear strength or other bulk sediment properties and the erosion shear stress and erosion rate using in-situ measurements. The work of Briaud et al. (2001) testing soil samples in the Erosion Function Apparatus (EFA) provides one way forward - in this case a sediment core is returned to the laboratory for erosion testing - but there are other methods that can be used to estimate the erosion resistance including ISIS (Williamson and Ockenden, 1996), SedErode (Mitchener et al., 1996) and SERF (Jiang et al., 2004). A review of erosion devices has been made by Black and Paterson (1997) and Annandale (2006). Information and approaches for predicting the erosion, transport and deposition of sands and muds have been published by (amongst others) Annandale (1995, 2006), Mitchener et al. (1996), Soulsby (1997), Winterwerp and van Kesteren (2004) and Whitehouse et al. (2000). Further clarification of the scour hazard of a range of multimodal and clay influenced soils is required, as - to date - it has not been possible to find a unique relationship between geotechnical measures of soil properties and hydraulic measures of resistance to erosion. The approach by Annadale (op. cit.) provides a practical approach for converting geotechnical measures into erosion parameters and has been used in the UK to evaluate the erosion resistance of clay and chalk based substrates. However, the ability of the approach to capture variations in scour sensitivity in the marine environment still requires validation through further analysis.

In the present research data from the marine environment has been collated to evaluate the sensitivity of different environments with offshore windfarm foundations to scour (DECC, 2008; Whitehouse et al., 2008). Here the dataset has been extended to include some additional non-windfarm data to provide a context for the windfarm analysis. The following sections of this paper indicate how variations of scour in time can occur, firstly in sandy non-cohesive soils and secondly in clay influenced soils.

\section{Overview of available datasets}

Data for scour in predominantly sandy sediments has been obtained for the Scroby Sands and Arklow Bank offshore windfarms as well as the Scarweather Sands and North Hoyle meteorological masts, as well as a location in the Dutch N7 sector of the North Sea and two locations in tidal inlets, the first at Otzumer Balje tidal inlet on the northwest coast of Germany and the second a road bridge pier at a tidal inlet near Destin on the Gulf of Mexico coast of Florida. The three windfarm sites which have seabed sediments influenced or underlain by clay are Barrow, Kentish Flats and North Hoyle. In all but two cases the foundation consists of a circular monopile. The two exceptions were the bridge pier near Destin, which has a square cross-section and one of the meteorological masts at North Hoyle, which has a tripod foundation. The Scroby and Arklow foundations had scour protection material placed and the scour around the edge of the scour protection (secondary scour) has also been analysed. 
The locations for which data has been collated in European waters are shown in Figure 2 covering a range of environments and providing information on both inter-site variation and intra-site variation from surveys typically collected every six months. The sites studied, whilst sharing some characteristics were all unique (Table 1). The American site referred to later is not shown on Figure 2.

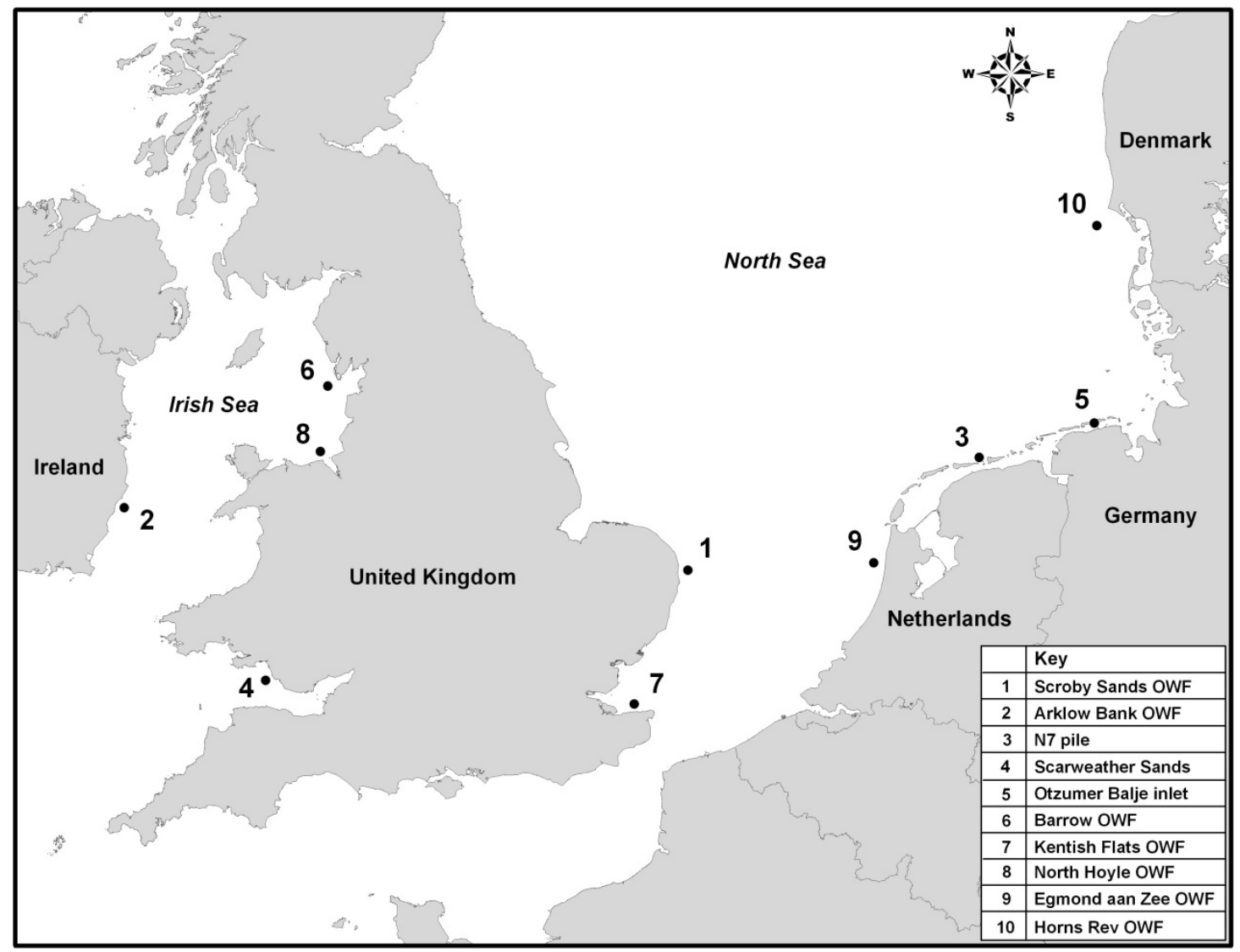

Figure 2: Locations of European study sites

The measure of scour was based on analysis of the surveyed ambient seabed level giving the water depth, $\mathrm{h}$, and the locally scoured seabed level around the foundation denoted by the horizontal dashed line; hence the scour depth $\mathrm{S}$ was calculated directly as the difference between these two values (Figure 3 ). The vertical accuracy of the depth data was typically $0.25 \mathrm{~m}$ and assuming the same accuracy applied in any one dataset the differences between values was calculated to the nearest $0.1 \mathrm{~m}$.

The key parameters in the dataset included:

- Structure information - dimensions and installation date;

- Environmental data - general information on water depth/variation, currents, waves, sediment type (summarised in Table 1); and

- Depth of scour at structure - defined as depth of hole below surrounding local seabed level at the time of survey (Figure 3).

For sites with multiple surveys it was possible to investigate temporal variations although short-term changes were not captured in the datasets for offshore windfarms. The sites and data are described in more detail below. 
Table 1: Site characteristics

\begin{tabular}{|c|c|c|c|c|c|c|c|c|c|c|}
\hline 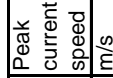 & $\begin{array}{l}\qquad \\
\text { : }\end{array}$ & $\approx$ & $\begin{array}{l}5 \\
2 \\
C\end{array}$ & 7 & $\stackrel{+}{-}$ & c & 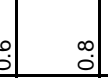 & : & $\underset{-7}{7}$ & \\
\hline 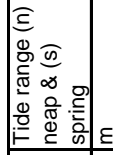 & 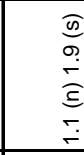 & $\begin{array}{l}\text { an } \\
\text { N } \\
\text { E } \\
-1\end{array}$ & 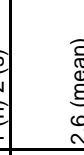 & 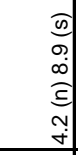 & 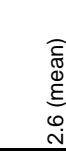 & $\begin{array}{l}\vec{x} \\
0 \\
\text { a } \\
\tilde{a} \\
0\end{array}$ & 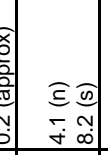 & $\begin{array}{l}\text { Eิ } \\
\text { on } \\
\text { is }\end{array}$ & 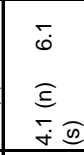 & \\
\hline 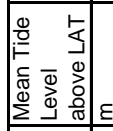 & - & $\stackrel{m}{-}$ & $\stackrel{*}{*}$ & $\begin{array}{c}0 \\
\text { in }\end{array}$ & - & 0 & in & $\begin{array}{l}\stackrel{+}{N} \\
\text { D }\end{array}$ & 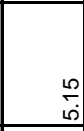 & 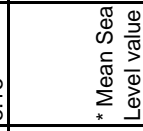 \\
\hline 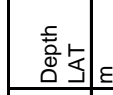 & $\begin{array}{l}\text { ज̃ } \\
\stackrel{0}{m} \\
\end{array}$ & $\begin{array}{l}\stackrel{0}{2} \\
\stackrel{2}{N}\end{array}$ & in & 0 & ㄱ. & $\stackrel{\infty}{m}$ & 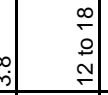 & $\begin{array}{l}n \\
\stackrel{2}{m} \\
m\end{array}$ & $\begin{array}{l}7 \\
0 \\
0\end{array}$ & \\
\hline 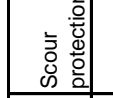 & $\stackrel{\substack{0 \\
\nu}}{2}$ & 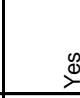 & $\frac{0}{2}$ & 2 & ₹ & $\frac{0}{2}$ & $\stackrel{0}{z}$ & $\stackrel{0}{z}$ & 요 & 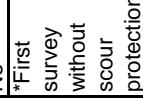 \\
\hline 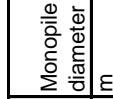 & $\underset{\mathcal{T}}{\mathcal{N}}$ & م & 0 & $\stackrel{N}{\sim}$ & نجم & $\overbrace{}^{*}$ & $\begin{array}{l}\stackrel{L}{f} \\
\underset{f}{*}\end{array}$ & ص & $\checkmark$ & 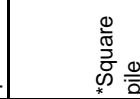 \\
\hline 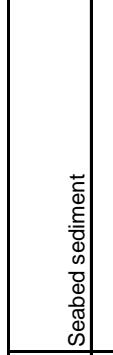 & 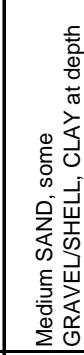 & 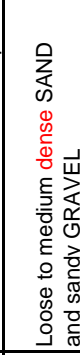 & 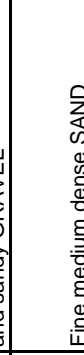 & 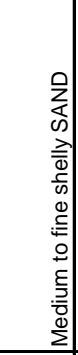 & 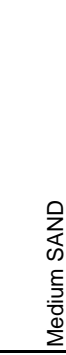 & $\begin{array}{l}2 \\
0 \\
0 \\
0\end{array}$ & 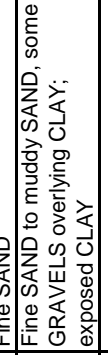 & 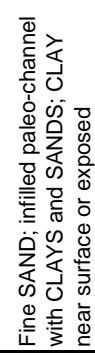 & 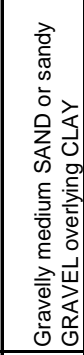 & \\
\hline 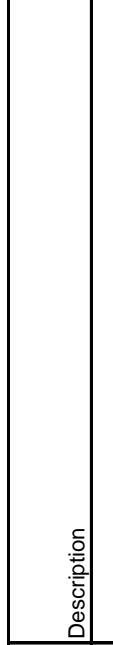 & 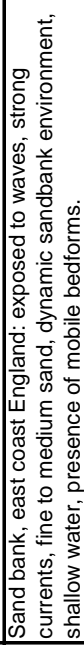 & 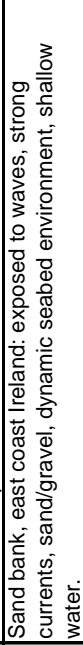 & 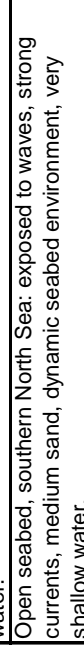 & 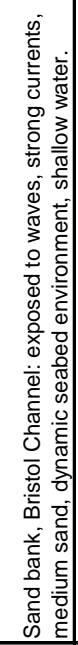 & 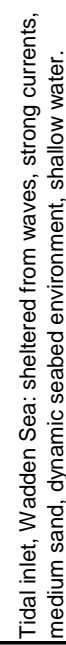 & 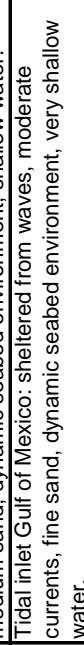 & 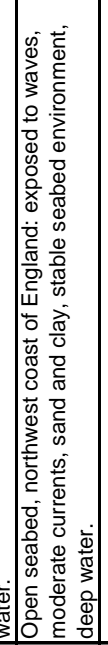 & 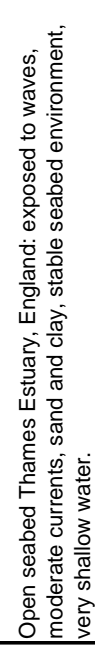 & 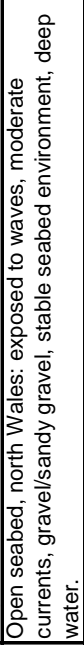 & \\
\hline$\frac{9}{5}$ & 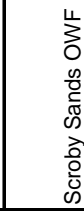 & 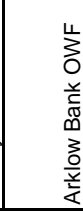 & $\mathrm{z}$ & 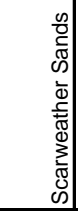 & 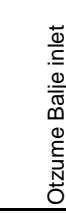 & 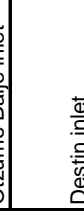 & 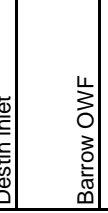 & 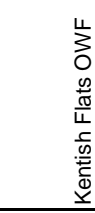 & 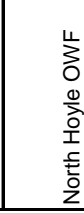 & $\begin{array}{l}\ddot{\omega} \\
\text { in }\end{array}$ \\
\hline
\end{tabular}




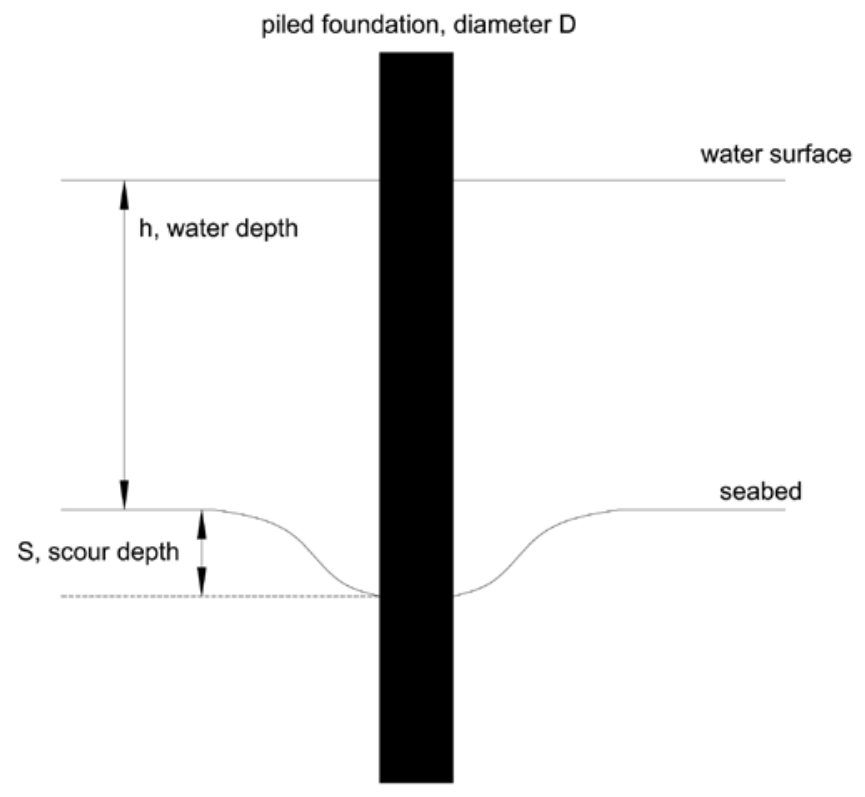

Figure 3: Scour definition

Later on in the paper the scour depth $\mathrm{S}$ and water depth $\mathrm{h}$ have been non-dimensionalised with the pile diameter $\mathrm{D}$, which is the recognized length-scale controlling the impact of the foundation on the ambient flow field and resulting sediment transport. This non-dimensionalisation of the scour depth is based on sediment transport theory and is used widely in the scour literature (Breusers et al., 1977; Hoffmans and Verheij, 1997; Whitehouse, 1998; Sumer and Fredsøe, 2002). Non-dimensionalisation of the water depth in this way is used to show whether the water depth for a specific structure is shallow, with relative values of h/D $<3$ to 5 generally taken to indicate shallow water (Whitehouse, 1998). Structures with values of $h / D$ greater than this are, for the purposes of scour analysis, considered to be in deep water. Using these two non-dimensional parameters allows the data to be compared in a clear and consistent fashion. The generic sediment properties referred to in Table 1 were used to categorize the sites into sandy seabed environments and clayinfluenced environments which was a central requirement for the analysis.

\section{Scour in sandy seabed sediments}

This section of the paper describes the details of the individual datasets for the offshore windfarm sites and for some complimentary datasets where scour has formed and been measured in sandy soils.

\subsection{Scroby Sands OWF}

The scour depths at this site were monitored in March 2004 following installation of all 30 of the $4.2 \mathrm{~m}$ diameter foundation piles. The foundations were installed in the period November 2003 to February 2004 so by the time of the survey some turbines had been installed four or five months whilst others had been installed for around a month. The scour depths recorded in the unlimited thickness of sandy sediment forming the bank ranged between $0.95 \mathrm{D}$ and 1.38D where $\mathrm{D}$ is the outer diameter of the monopile. This range of scour depths resulted from spatial variations in water depth and wave-current exposure as well as the time elapsed since installation. With the information presently to hand the minimum period for scour to form to a significant proportion of its ultimate value was not known since the surveys were taken at approximately six month intervals. However, according to den Boon et al. (2004) scour was formed in a few 
tidal cycles before scour protection was installed in the scour holes. A similarly rapid development of scour on spring tides was also referred to by Høgedal and Hald (2005) and Ottesen Hansen and Gislason (2005). A typical scour pit from March 2004 is shown in Figure 4a. The scour protection was installed between February and May 2004 and a typical scour pit with scour protection in place is shown in Figure 4b.

(a)

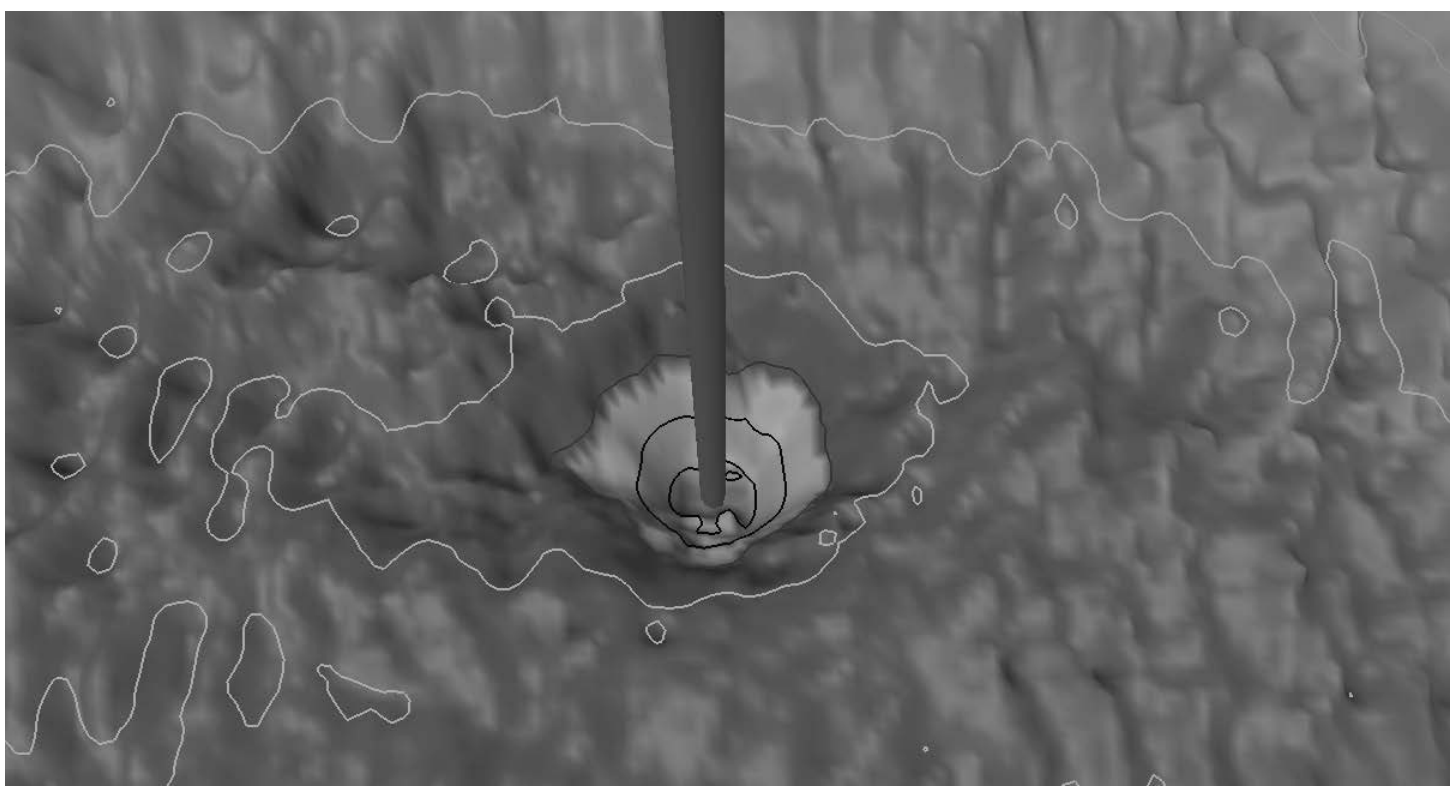

(b)

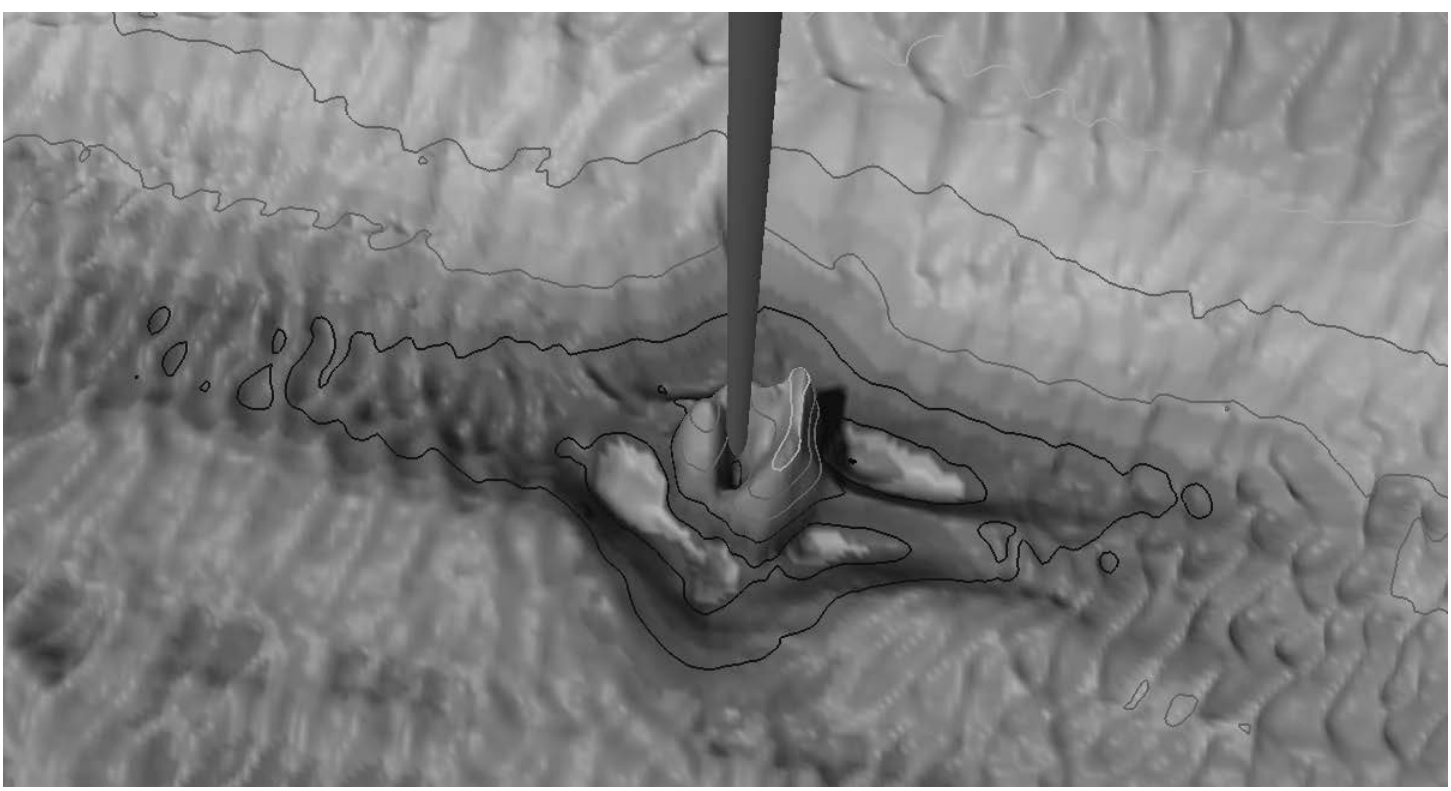

Figure 4: (a) A typical Scroby windfarm scour hole (WTG01 March 2004)); (b) a typical scour hole with scour protection material installed (WTG01 September 2005). Views looking east with depth contours at $1 \mathrm{~m}$ intervals (vertical exaggeration x 10) 
Figure 5 shows the scour hole profiles at three turbine locations before scour protection was installed and how the holes changed following installation of the scour protection. Whilst the turbines were located less than $400 \mathrm{~m}$ apart the scour depths were very different at the time of the survey. Following installation of scour protection in the scour holes from a side dumping barge the local scour depth around the edge of the protection at two of the turbines shown in Figure 5 (01 and 09) was deeper in September 2005 whereas at turbine 05 the scour depth was reduced. The survey also showed the sandbank surface level had changed by $1 \mathrm{~m}$ or more away from the turbines themselves since this is a dynamic sediment transport environment. From all the available survey data collected over a period of 32 months the ambient bed depths were in the range $3 \mathrm{~m}$ to $11.5 \mathrm{~m}$ below Chart Datum (CD) in March 2004 and $3 \mathrm{~m}$ to $11 \mathrm{~m}$ below CD in November 2006. This confirmed a tendency for the bank to be generally stable although the bed levels at any individual turbine location changed through time.

Scroby N-S section at Turbines \#01, 05 and 09

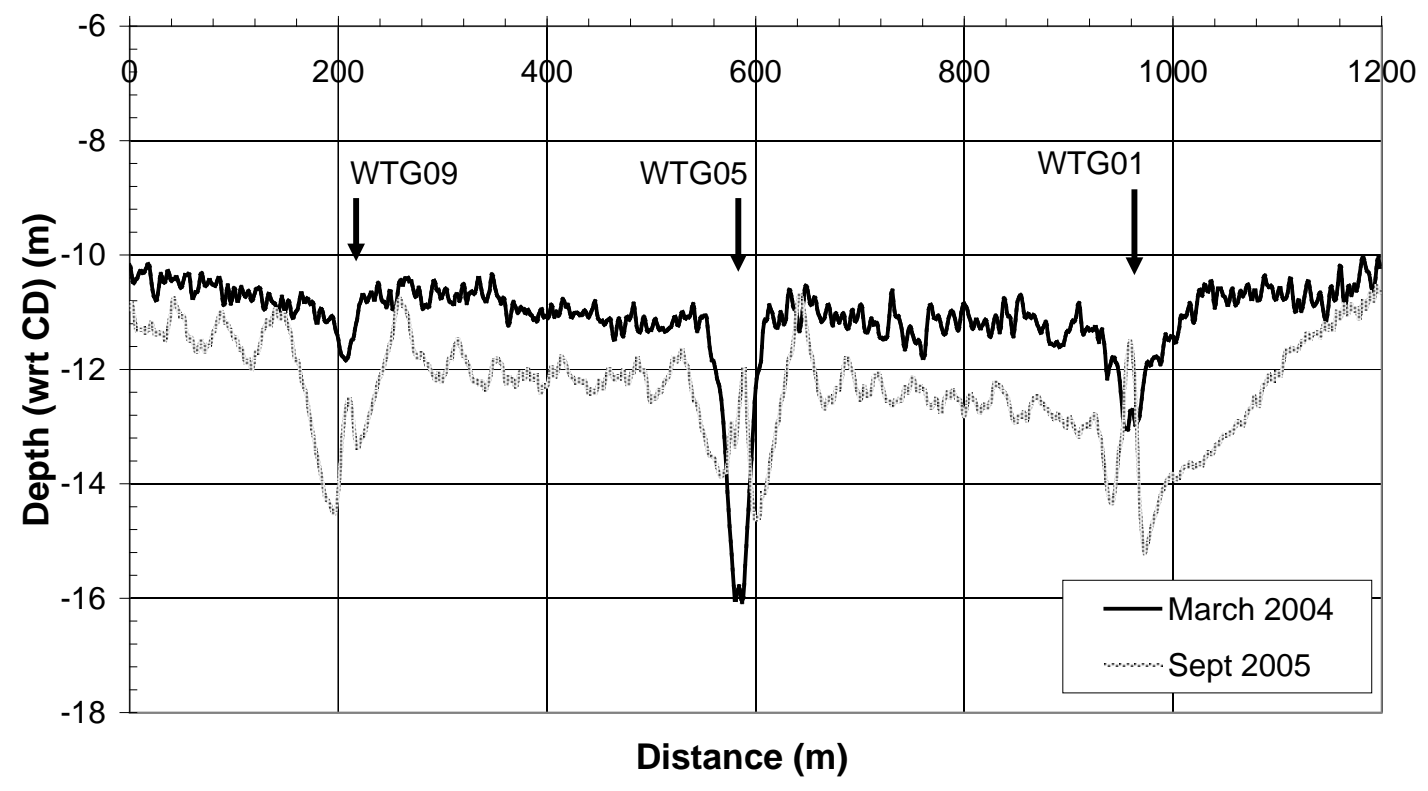

Figure 5: Measured seabed levels along a section intersecting Scroby Wind Farm Turbines 01,05 and 09 (note: vertical scale heavily exaggerated)

More details of the data with scour protection are given in a later section of this paper.

\subsection{Arklow Bank OWF}

The scour depth was measured following installation of the seven wind turbines over a period of nine weeks during late summer and early autumn in 2003. There was a short delay of unknown duration between installation of the $5 \mathrm{~m}$ diameter monopile foundations and the installation of scour protection rock. This time was sufficient for scour holes to develop around the monopiles due to the tidal current alone. Sidescan sonar was used to measure the size of the scour holes and an example of a contour plot derived from sidescan sonar is shown in Figure 6 (reproduced from Figure 4 of Whitehouse et al., 2006). The scour hole was fairly symmetrical, with smooth sides and was about $0.8 \mathrm{D}$ deep. It had a similar depth and shape to the scour hole measured in the laboratory tests with a mobile sand bed reported by Whitehouse et al. (2006). 
The scour protection was installed in the pre-formed scour holes from a jackup barge with a back-hoe grab. As with Scroby details of the data with scour protection are given in a later section of this paper.

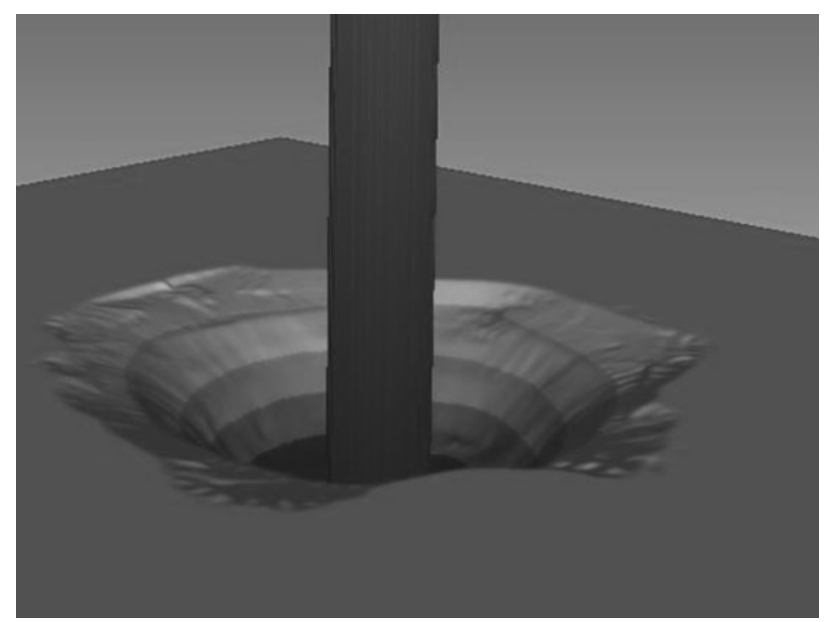

Figure 6: A typical measured scour hole shape at Arklow before scour protection was added (from Whitehouse et al., 2006)

\subsection{Monopile in N7, Dutch Sector North Sea}

Data has been published (Rudolph et al., 2004) for the scour development over a period of nearly five years around a $6 \mathrm{~m}$ diameter monopile foundation. The maximum scour depth after 9 months was $0.55 \mathrm{D}$ and after nearly five years 1.05D as shown in Figure 7. The rate of development of scour had slowed at this time but had not necessarily ceased. The average scour pit depth around the circumference of the pile observed at the same times, 9 months and five years, were lower - namely 0.5D and 0.8D. The data appears to indicate a progressive increase in scour although it provides snapshots on a time-varying process and hence it is not known whether the scour depths were deeper or shallower periodically during un-surveyed periods, for example as a result of storms, and the role of antecedent conditions on the scour development at the time of the surveys. 


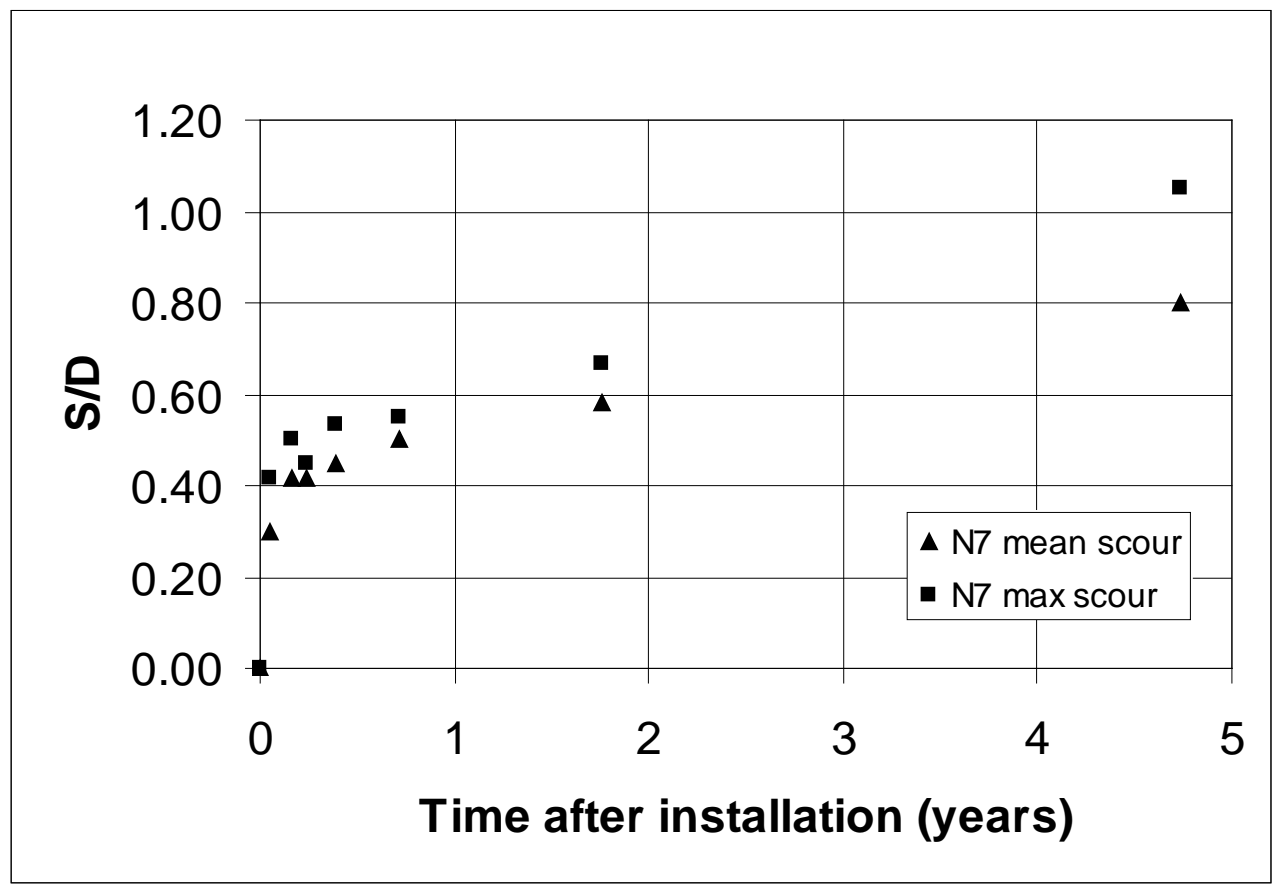

Figure 7: Time development of scour at N7

\subsection{Met Mast on Scarweather Sands sandbank}

The data for this sandbank site with medium grade sand relates to the $2.2 \mathrm{~m}$ monopile met mast foundation (Harris et al., 2004). The foundation was installed in May 2003 and the measurements were made in the latter part of June of the same year. The time variation in scour depth was measured using a multi-beam echo sounder which showed the scour profiles. North-south and east-west intersecting transects through the met mast location are shown in Figure 8 which show the variation in scour hole profiles at high water and low water and the movement of the bed and imposed bed features. The data showed that under tidal variation there was a temporal variation in scour depth. The average scour depths were determined from the survey data at high water and low water and were found to vary between 0.27D and 0.59D, respectively, relating to the varying strength of current and wave action through the tide. 

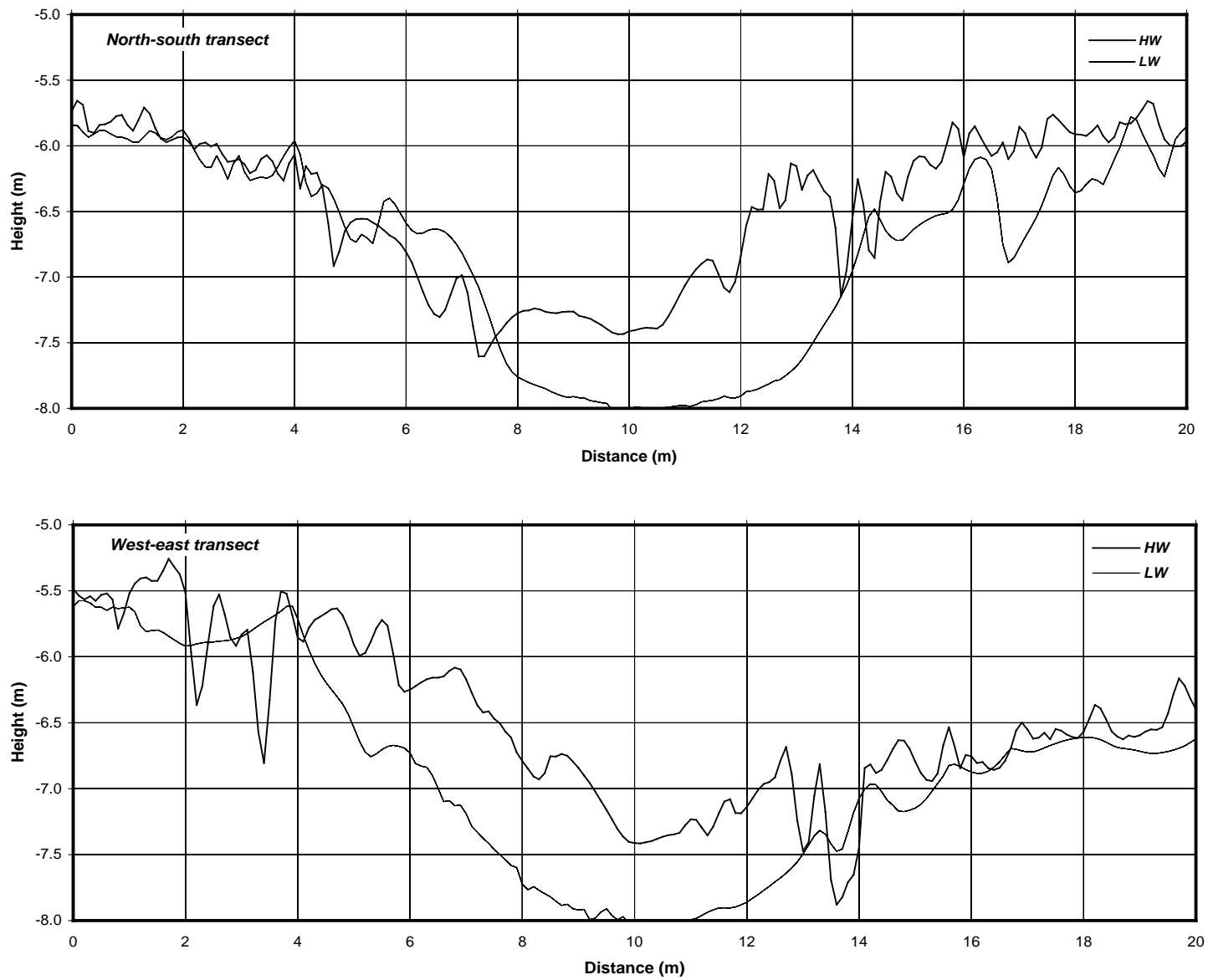

Figure 8: Variation in scour depth with distance and time in tide at Scarweather Sands met mast

\subsection{Egmond aan zee OWF}

Louwersheimer et al. (2009) reported on scour at the met mast for the Egmond aan Zee offshore windfarm with foundation diameter $2.9 \mathrm{~m}$. This had been installed without scour protection in a medium grade sand seabed with $d_{50}$ of $0.25 \mathrm{~mm}$. A survey taken after three years indicated scour at the monopile was $2.3 \mathrm{~m}$ in $20 \mathrm{~m}$ of water. Therefore the non-dimensional scour depth was $S / D=0.7$.

\subsection{Monopile foundation Otzumer Balje Inlet}

The scour data for this site was published by Noormets et al. (2003). A monopile foundation with diameter of $1.5 \mathrm{~m}$ was installed in a tidal channel of the Wadden Sea which was sheltered from wave action. The survey data five to six months after installation indicated a scour hole of 1.47D. There was some evidence for variation in the scour depth between spring and neap tides, with the scour hole being shallower by $0.27 \mathrm{D}$ on neap tides. The non-dimensional ratio of scour depth $S / D=1.47$ on spring tides was the largest value found for a field site in the present study. This was presumably due to the constrained rectilinear nature of the tidal flows past a slender pile in deep water causing scour without the infilling effect of wave action. 


\subsection{Destin tidal inlet bridge pier}

Field data for the tidal-scale time-variation of scour in the marine environment are few and far between. A well documented test from the USA (Walker, 1995) provided information about how scour develops in tidal current conditions at a bridge with a known scour condition across a tidal inlet on the Gulf of Mexico, in northwest Florida. The bridge pile was sheltered from waves and hence similar in setting to the Otzumer Balje site. The pile was square in cross-section with a width of $0.61 \mathrm{~m}$ and the deepest scour depth observed was about $1.1 \mathrm{~m}$. Instrumentation was installed as illustrated in Figure 9a and consisted of a video camera for time-lapse video monitoring of the scour hole, two underwater lights for night time operating, an acoustic transponder to measure the scour hole depth aimed at a point at the base of the exposed pile to track the maximum depth of scour and an electromagnetic current meter. The instrument package was mounted onto the pier, after removing marine fouling, using an aluminium frame to create a large clamp and form a stable and non-obtrusive measurement platform.

The water at this location was generally clear and the sediment was cohesionless and relatively uniform in size with a median grain size, $d_{50}$, of $0.28 \mathrm{~mm}$. The pier was skewed to the flow running from corner to corner as shown in Figure 9a; the projected dimension of the pier between corners orthogonal to the flow was therefore $0.86 \mathrm{~m}$. The measured current velocity is shown in Figure $9 \mathrm{~b}$ together with the measured scour depth. The pre-existing scour hole was filled with sand from the surrounding area and then the scour process was monitored continuously through a spring tidal cycle. There was some concern that the sand fill was at a lower density than the surrounding seabed but this only remained looser for about a day (Walker, 1995). The scour hole scoured to it's previous depth in the duration of the measurement period (8 days) - this is the period of data shown in Figure 9b. The data showed the way in which the scour depth increased with each tide despite periodic infilling of the scour hole at the measurement location due to the reversing tide direction. The flow on the outflow phase was generally very turbulent with high suspended sediment concentrations which led to some masking of the bed to the acoustic signal during the periods of peak flow (e.g. the box marked signal drop out on the measured scour depth signal shown on Figure $9 b$ and similarly elsewhere in that record). 


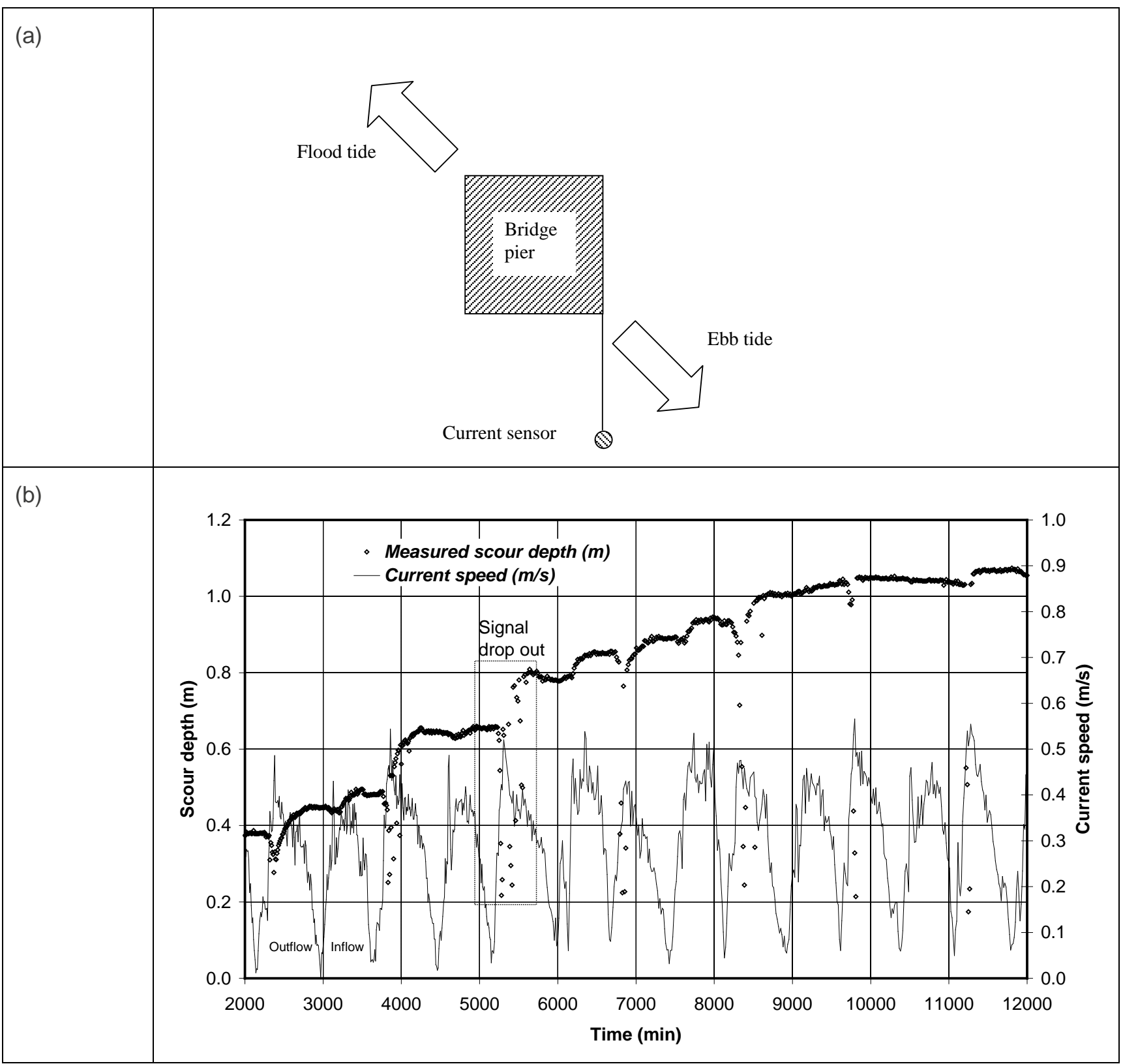

Figure 9: (a) Schematic of bridge pier showing flow orientation (after Walker, 1995)

(b) Time variation of current speed and scour depth at a $0.61 \mathrm{~m}$ square section pile on the East Pass Bridge, Destin, FL over an 8 day period 


\section{Scour at clay influenced sites}

Data for scour development in clay influenced sites has been obtained from the foundations at Barrow, Kentish Flats and North Hoyle (Figure 2). The type of data collected was the same as for the sandy sites. The site characteristics are described in Table 1 and the scour is described below.

\subsection{Barrow OWF}

Scour was measured at thirteen out of 30 of the $4.75 \mathrm{~m}$ diameter monopile foundations at Barrow in July 2005 , within nine weeks of completing the installation of the first monopile. Scour depths up to $S / D=0.44$ were observed in the sandy deposits in the west of the site. Much lower scour depths (up to $S / D=0.04$ ) were measured in the glacial till to the eastern side of the wind farm. There was some indication that scour depths in the glacial till increased slowly with time following installation and, to a lesser extent, this was also picked up at the sites with sand at the surface (DECC, 2008). Depressions from the spudcan footings of the jack-up barge used for installation were also visible in the seabed.

In September 2006 all thirty of the foundations were re-surveyed. The observed scour depths in areas with a good thickness of sandy sediment had increased to a maximum value of $S / D=1.21$. A typical scour pit is shown in Figure $10 a$ with a depth of $4 \mathrm{~m}(S / D=0.84)$. In the areas with a superficial cover of sand the scour depths were limited by the thickness of that layer to scour depths of up to and around $0.5 \mathrm{~m}$ or $0.1 \mathrm{D}$ in clay sites. Figure $10 \mathrm{~b}$ shows one of the clay sites with an indistinct scour hole of up to $0.5 \mathrm{~m}$ in depth.
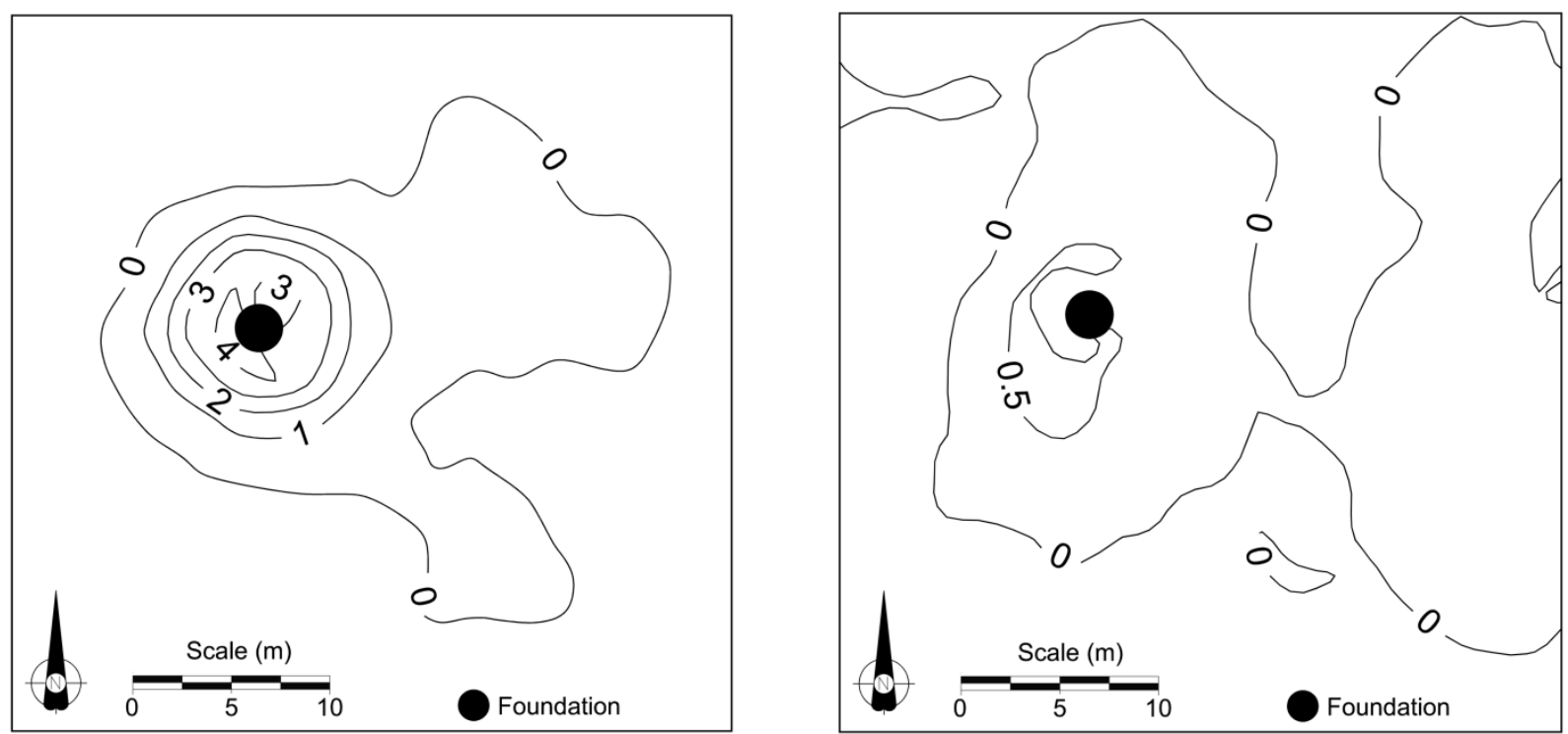

Figure 10: (a) Example of measured scour hole in sand seabed at Barrow - contours at 1m interval below ambient bed level (b) Example of measured scour hole in clay seabed at Barrow - scour contour at $0.5 \mathrm{~m}$ below ambient bed level

The key parameters which determine the amount of scour are the composition and thickness of the surficial and sub-surface sediment layers as well as the prevailing hydrodynamic conditions. Figure 11 shows the measured scour depths for all 30 of the monopiles with respect to the thickness of the surficial sediment layer. In Figure 11 line A indicates where scour equals the depth of superficial sediment and line $B$ is $S / D=$ 1.3 following the guidance of DNV (2007). Whilst seven of the turbines had well developed scour it is clear that at the majority of the sites scour had been restricted by the thickness of the surficial layer and the 
resistant properties of the underlying soils. The turbines that experienced the greatest scour were those that lay to the west where the bed consisted of fine to medium sand and the thickness of the surficial layer was greatest. The depth-limited cases generally lay to the east where the sea bed consisted of glacial till and for the case with $0.5 \mathrm{~m}$ or less of sediment cover the scour formed with this limiting effect is typically as shown in Figure 10b.

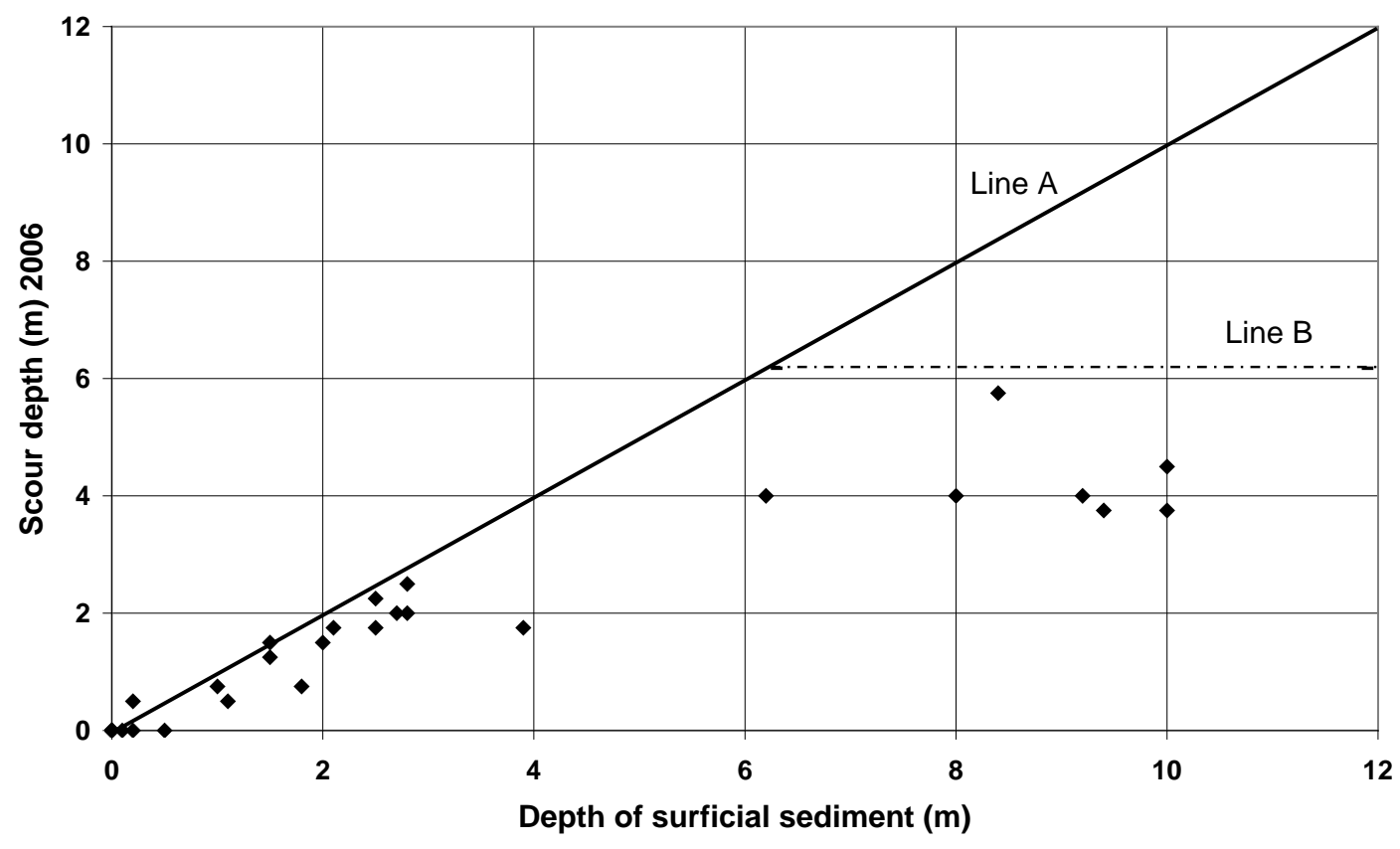

Figure 11: Scour depths measured at Barrow as a function of the depths of surficial sediment

\subsection{Kentish Flats OWF}

Depressions were measured at four of the $5 \mathrm{~m}$ diameter turbine foundations in January 2005, some three months after completion of the 30 turbine foundations. The sites monitored were on the east side of the turbine array and the seabed had surficial covers of fine sand and shell overlying clay, accept at those foundations located within the infill deposits in a palaeo river channel running across the site where there were greater thicknesses of sands and clays present. It was not clear how much of the initial "scour" depression around the turbines was due to hydraulic scour processes, or whether it was caused by "drawdown" of the soil during foundation installation. Depressions were evident in the seabed surveys at the locations where the jack-up barge legs had been present during installation, most probably due to penetration of the legs into the soil rather than through scour processes.

Assuming the depressions around the foundations were caused mainly by scouring processes the maximum measured depth was less than 0.28D in January 2005, increasing to 0.46D in November 2005 and decreasing again to $0.34 \mathrm{D}$ in April 2006. The picture of change was complex as the scour at one location increased with time during the three surveys whereas the scour at the other three locations increased in the first two surveys and then decreased in the last survey. Assuming consistency of the surveys, and the time variations were not an artefact arising from survey error, this suggested that seabed sediment transport processes were able to produce fluctuations in the depth of the scour around the foundations at this site. 


\subsection{North Hoyle OWF}

\subsubsection{Turbine foundations}

The scour depths were first measured from a survey conducted in the period August to October 2004. The 30 foundation monopiles were $4.0 \mathrm{~m}$ diameter and were installed over the period April to July 2003. The bed sediments were predominantly gravels and sandy gravels which were of relatively low mobility and below the top metre of material there was more compact gravelly clay which provides a resistant (but not necessarily inerodible) horizon.

The scour recorded in the 2004 survey was less than $0.125 \mathrm{D}$ - although scour was recorded at only ten of the 30 foundations - and in a survey conducted in April-May 2005 no scour was recorded at any of the foundations. No scour protection material was placed although there was some redistribution of drill cuttings on the seabed which had arisen during the drill-drive process used to install the foundations.

\section{Meteorological masts}

Survey data was available from the three met masts adjacent to the wind farm site, all with slender foundation piles. The scour depth in 2004 at the $3.2 \mathrm{~m}$ monopile met mast 1 was (with some uncertainty) $0.09 \mathrm{D}$ and at the tripod foundation met mast 2 the scour depth was $0.39 \mathrm{D}$ around each of the three $0.76 \mathrm{~m}$ diameter sloping piles. The scour depth recorded in 2004 at the $1.89 \mathrm{~m}$ diameter met mast 3 on Constable Bank to the west of the wind farm was $0.79 \mathrm{D}$. The pattern of scour observed in the next annual survey collected in 2005 was different in detail but the scour depth was the same.

\section{Overall assessment of scour results}

The assembled data has been brought together and plotted in a consistent fashion on Figure 12 using the ratios of scour depth to pile diameter $(S / D)$ and water depth to pile diameter $(h / D)$. The other relevant site parameters were listed in Table 1 which included a brief description of the sediment conditions to facilitate comparison of the scour data. Figure 12 indicates how the scour compares between sites and within sites with different ambient water depth, i.e. water depth away from the influence of scour (defined in Figure 3). This figure shows that the data from the different sites occupy a number of clusters. The deepest scour recorded was $S / D=1.47$ in the current-dominated sandy environment of the Otzumer Balje inlet at a slender pile after 5 to 6 months. The deepest scour, for one of the windfarm foundations at Scroby Sands, had a ratio $S / D=1.38$ after four to five months, exceeding the value in DNV guidance (2007) recommended as S/D $=1.3$. The largest scour depth in sand at Barrow $(S / D=1.21)$ was obtained more than one year after installation of the piles. It is expected that the Scroby data could have developed quite fully by the time it was surveyed, and reached equilibrium depth, although the influence of the flow and wave conditions just prior to the survey may have had an unknown influence on the scour depth. As indicated by the incremental nature of the scour data for N7 (Figure 7) it is possible that scour can increase over periods of years on sandy sediments. All the data from N7 is plotted on Figure 12 to show the range of scour that was observed since installation over almost 5 years. The growth of the N7 scour spans the gap in scour depths between the largest scour depth at Kentish Flats and the lowest depths at Scroby Sands. Confirmation or otherwise of similar scour behaviour at the other sites in this paper would be picked up by future monitoring of seabed levels and analysis for scour. 


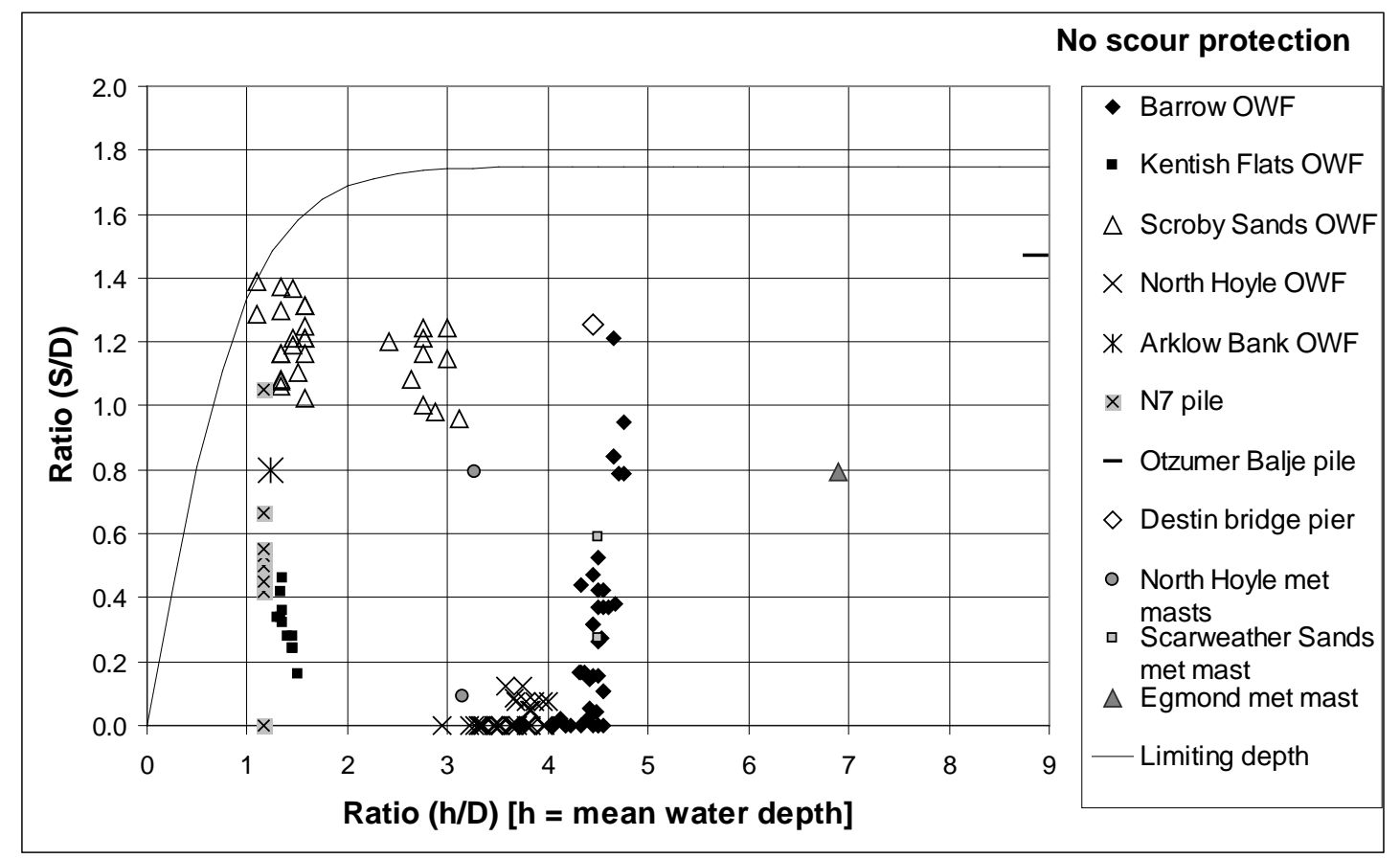

Figure 12: Relative scour depth against relative water depth without scour protection

The controlling influence of sediment type highlighted in Figure 1 is evident in the Barrow data shown on Figure 12, where the near zero scour depths occur on the glacial till bed material, or at those locations where the surficial layer thickness has a limiting effect, and the higher values occur where sand is not limited by the restricted sediment thickness. Similarly low values of scour were seen at North Hoyle where there was a less mobile gravelly bed overlying more resistant gravelly clay, and at Kentish Flats where there was a layer of fine sand overlying clay. Scroby Sands and Arklow Bank both had thick sandy deposits, with the sediment being coarser at Arklow than at Scroby. The Scroby and Arklow sites have the strongest currents and though the other sites investigated have smaller currents, these are still capable of mobilising sand but not gravels or clay sediments. The Barrow, Kentish Flats and North Hoyle have slightly less wave exposure than the other sites investigated, lower current speeds, and hence potentially less dynamic sediment transport environments.

The results for the North Hoyle met mast 1 lies in the low scour depth cluster for Barrow and has a similar depth to the wind farm foundation values for North Hoyle. The relative scour depths at met masts 2 and 3 are deeper than the North Hoyle wind farm foundation values. The two Scarweather Sands met mast datapoints lie above the North Hoyle data and below Scroby Sands. For comparison a datapoint representing the scour after three years at the met mast for the Egmond aan Zee windfarm has been added to Figure 12. The scour at the square pile on the Destin bridge site has been non-dimensionalised with the diagonal length between two opposite corners of the cross-section (i.e. $0.86 \mathrm{~m}$ ) rather than the length of the side $(0.62 \mathrm{~m})$. This is strictly correct as it is more closely represents the projected area presented by the pile to the flow (Figure 9a).

From analysis of all the windfarm foundations in the dataset it was determined that only six of the 115 values were greater or equal to the value of $S / D=1.3$ adopted in the guidance for offshore windfarms (DNV, 2007). It is relevant to note that empirical formulae for scour prediction (Hoffmans and Verheij, 1997; Whitehouse, 1998; Sumer and Fredsøe, 2002) indicate a reduction in scour depth with a reduction in water depth, for values of the ratio h/D which are less than 3 to 5 . Following the approach of den Boon et al. (2004) the 
maximum scour depth that can be expected based on analysis of laboratory data was $S_{\max } / D=1.75$ and the effect of limited water depth was taken into account by introducing a factor $S_{\max } / D \times \tanh (0.75 \mathrm{~h} / \mathrm{D})$. The expression for limiting depth was adapted from the Breusers et al. (1977) formula by Soulsby (personal communication, 2004) to give a good fit to laboratory data shown in Fig. 3.26 of Sumer and Fredsøe (2002). This independently derived curve has been plotted on Figure 12, marked "limiting depth", and can be seen to provide a bounding curve that is above the presently assembled dataset. Future datasets will confirm the general applicability of this relationship.

\section{Scour protection options}

There are a range of approaches that can be taken to prevent or mitigate against scour around foundations, either planned for or as a remedial measure if scour is more severe than was expected. Scour protection options are reviewed by Whitehouse (1998) including, amongst other methods, geotextile containers/sandbags, concrete armour units, concrete block mattresses, grout bags/mattresses, gabions/gabion mattresses and flow inhibitors.

Rock armour has been the most commonly used form of scour protection at OWFs using gravel, quarry run stone or blasted rock (usually limestone or granitic rocks although slate has been used at Burbo Bank OWF) to cover a particular area of seabed to a specified thickness. The approaches that have been taken to use of rock armour are:

- Placement of small sized rock or gravel directly on the seabed as a preparatory layer; this acts as a filter layer on the seabed and can be placed before installation of the foundation or before scour has had time to develop

- Placement of larger rock as an armour layer on top of the preparatory filter layer. There are well known criteria for ensuring stability of interface layers in these types of systems (e.g. Whitehouse, 1998) but given the practicalities of offshore installation it is not always possible to follow these strictly.

- Placement of widely graded rock in the scour hole around the structure

The influence of rock armour on scour will be considered in more detail below. 


\section{Experience from sites with rock armour protection}

\subsection{Rock armour placed around the foundation}

Scour protection has been applied at offshore windfarm foundations in the Danish and Dutch sectors. These have used the approach of pre-installed filter layer and rock armour on top (Figure 13).

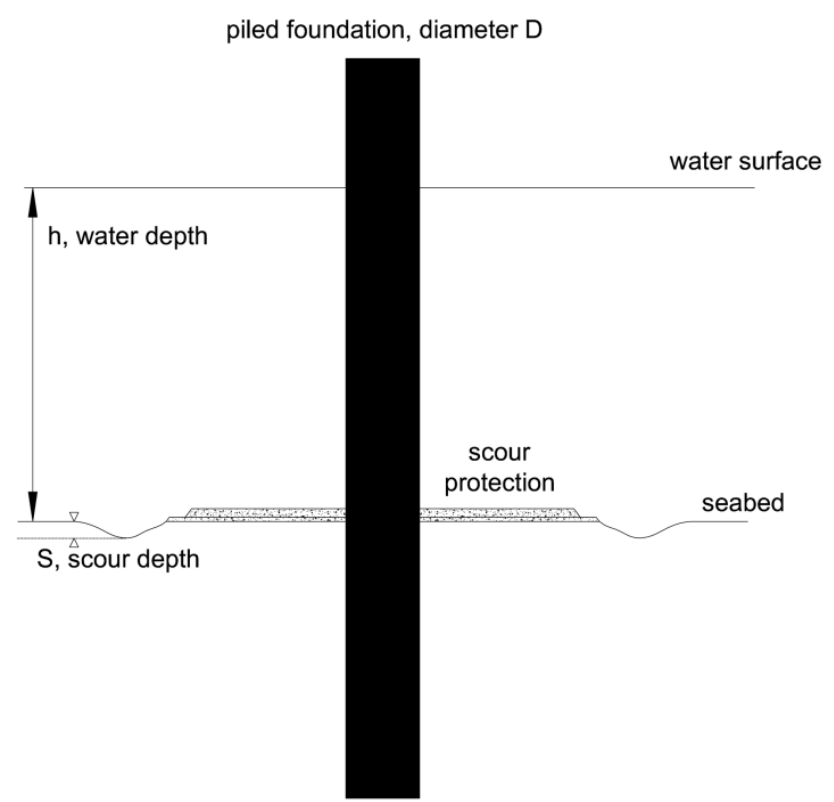

Figure 13: Secondary or edge scour definition with scour protection in place - protection laid on seabed

\subsubsection{Horns Rev OWF (Hansen et al, 2007)}

At Horns Rev the circular monopile foundations are approximately $4.25 \mathrm{~m}$ outside diameter situated in water depths of 6 to $13 \mathrm{~m}$ below mean sea level. The seabed consists of fine to coarse sand $\left(d_{50}\right)$ in the range 0.15 to $1 \mathrm{~mm}$. The site is exposed to severe wave conditions - extreme waves and currents of $8 \mathrm{~m}$ and $1 \mathrm{~m} / \mathrm{s}$ are predicted. The foundations were all protected against scour by a $0.5 \mathrm{~m}$ thick filter layer placed on the sand bed with a $1 \mathrm{~m}$ thick armour layer placed on top all within a radius of $9.5 \mathrm{~m}$ from the centre of the monopile. Table 2 details the material used, where $d_{n}$ is the diameter of sieve through which $n \%$ by weight would pass.

Table 2: Seabed and scour protection material at Horns Rev (Hansen et al., 2007)

\begin{tabular}{|l|c|c|c|}
\hline Sizes in $\mathrm{mm}$ & $\mathrm{d}_{15}$ & $\mathrm{~d}_{50}$ & $\mathrm{~d}_{85}$ \\
\hline Seabed sand & 0.1 & 0.5 & 1.0 \\
\hline Filter rock & 20 & 100 & 200 \\
\hline Armour rock & 370 & 400 & 550 \\
\hline
\end{tabular}

The overall thickness of the scour protection layers was around $1.5 \mathrm{~m}$ and multibeam survey results of the scour protection from 2002 and three years later in 2005 showed there was some lowering of the surface both within and around the protection. Erosion of up to $0.5 \mathrm{~m}$ occurred outside the scour protection on the side opposite to that from which the main wave activity arrived at the site, i.e. down-wave direction. This depth equated to $0.12 \mathrm{D}$ or about one-third of the height of the protection layer. In spite of the accuracy of the 
data, quoted as $0.2 \mathrm{~m}$ in elevation, analysis of the surveys indicated a relocation of stones within the protection. There was also some lowering of the protection adjacent to the foundation of up to $1.5 \mathrm{~m}$ locally (0.35D), due to movement of armour within the protected area or downwards movement. Hansen et al. (op. cit.) indicated that some of the smallest stones in the filter layer may be lost through the armour layer and that there would be a possibility of the transport of sand, i.e. in the present case finer than 0.35 to $0.45 \mathrm{~mm}$, through the filter layer. The top level of the scour protection at the time of the survey remained above the seabed level.

Measures to mitigate against such lowering are to match the required seabed-filter stability criteria; this would require finer filter material or a geotextile underlayer which is difficult to place in offshore operations. Another option which is considered practical is to apply a thicker filter layer with a wider gradation, or to top up the armour layer as part of a maintenance programme.

\subsubsection{Egmond aan Zee OWF}

Two studies of the Egmond aan Zee offshore windfarm have been reported by Raaijmakers et al. (2007) and Louwersheimer et al. (2009) for a medium grade sand with $d_{50}$ of $0.25 \mathrm{~mm}$. The windfarm was completed in 2006 and comprises 36 turbines of $4.6 \mathrm{~m}$ outside diameter foundations with scour protection in water depths of 16 to $21 \mathrm{~m}$ below mean sea level.

The scour protection comprised two layers of material (Table 3). A filter layer of $0.4 \mathrm{~m}$ thickness comprising a nominal median rock size of $0.05 \mathrm{~m}$ and an armour layer of $1.4 \mathrm{~m}$ thickness formed from $0.4 \mathrm{~m}$ sized rock. The filter material was dumped first with a minimum extent of $24 \mathrm{~m}$ diameter and the pile and transition piece installed. The towers, turbines and cables were installed and the rock protection completed by rock dumping to a minimum diameter of $18 \mathrm{~m}$ on top of the filter layer.

Table 3: Seabed and scour protection material at Egmond

\begin{tabular}{|l|c|}
\hline Sizes in $\mathrm{mm}$ & $\mathrm{d} 50$ \\
\hline Seabed & 0.25 \\
\hline Filter & 50 \\
\hline Armour & 400 \\
\hline
\end{tabular}

Louwersheimer et al. (2009) investigated the filter performance around the turbines after periods of elapsed time of 13 to 114 days. They found that average filter bed lowering over the whole protection was in the range 0.07 to $0.11 \mathrm{~m}$ and that a longer period of exposure did not necessarily result in more lowering. $A$ lowering of the filter layer within $1.5 \mathrm{~m}$ of the monopile of about $0.4 \mathrm{~m}$ was caused when driving the monopile through as-built thicknesses of 0.4 to $0.7 \mathrm{~m}$. Edge scour outside the filter over the time monitored was low with indicative values up to $0.2 \mathrm{~m}$, i.e. 0.04D.

Subsequent analysis by Raaijmakers et al. (2007) of the edge scour depths around the fully protected foundation after a period of just over a year were found to be related to the flood tide, i.e. in the north-east quadrant downstream from the dominant tide direction - other than one location - and at a distance of 4 to $5 \mathrm{D}$ from the pile. The as-built armour layer thickness was in the order of 1.7 to $2.2 \mathrm{~m}$ with an extent of four times the pile diameter. Depths of edge scour were in the range $0.7 \mathrm{~m}$ to $1.6 \mathrm{~m}$, i.e. $0.15 \mathrm{D}$ to $0.34 \mathrm{D}$ or $30 \%$ to $90 \%$ of the nominal scour protection thickness. The edge scour location is important since it can be used to determine the optimum location for cable runs thus avoiding areas subject to erosion or enabling additional scour protection material to be placed for cable protection. 
There was also deformation of the armour layer within the first year after installation (2006/07). The scour protection experienced an overall lowering of 0.1 to $0.6 \mathrm{~m}$, determined as an average value over the protected area. Close to the piles the bed lowering was larger, in the order of 0.2 to $0.8 \mathrm{~m}$. Some material was spread around the edge of the scour protection but there was no evidence for material having been spread over a wider area. Raaijmakers et al. (2007) concluded that the deformation had been influenced by winter storms but that there may have also been settlement of the rock protection.

\subsection{Rock armour placed in the scour hole around the structure}

Scour protection has been placed once the scour hole has formed around the foundation at two sites, Scroby Sands and Arklow Bank (Figure 2 and Table 1).

\subsubsection{Scroby Sands OWF}

The scour protection installed around the $4.2 \mathrm{~m}$ diameter foundations at Scroby Sands was a mixed material of pebbles and gravel $(10 \mathrm{~mm}<\mathrm{d}<300 \mathrm{~mm})$ with a median size $d_{50}$ of $150 \mathrm{~mm}$ side dumped from a side dumping barge into the scour hole in six quadrants starting with the barge at $2 \mathrm{~m}$ from the foundation and moving away whilst unloading (Ottesen Hansen and Gislason, 2005). The material was mixed with gravel to provide a geotechnical filter function with the underlying sand seabed. Ottesen Hansen and Gislason (op. cit.) state the scour hole was filled up to $1 \mathrm{~m}$ below the existing sea bottom with a volume of $900 \mathrm{~m}^{3}$ of stones per foundation. Despite this apparent freeboard between the top of the scour rock and the seabed secondary scour has formed around the rock dump (Figures $4 b$ and 14 ).

The dataset from September 2005 plotted in Figure 5 shows a section of seabed levels traversing turbines 1 , 5 and 9 with rock protection having been installed. The mounds of scour protection are clearly visible, as is the secondary scour around them. Cross-sections of bed levels through the Scroby site until November 2006 indicated that the top level of the scour protection had not changed significantly since installation, although it was expected that some of the rock had moved out from the placed area into the secondary scour hole around the protection, i.e. in the form of a falling apron where the displaced rocks lie in an openly spaced layer on top of the sediment bed. The scour at wind turbine 5 was reduced from the March 2004 profile indicating the scour protection was acting to reduce the scouring, whereas the scour at the other two locations was deeper with the scour protection in place, but offset from the monopile location. The deepest scour occurs around 2 to $4 \mathrm{D}$ from the monopile. 


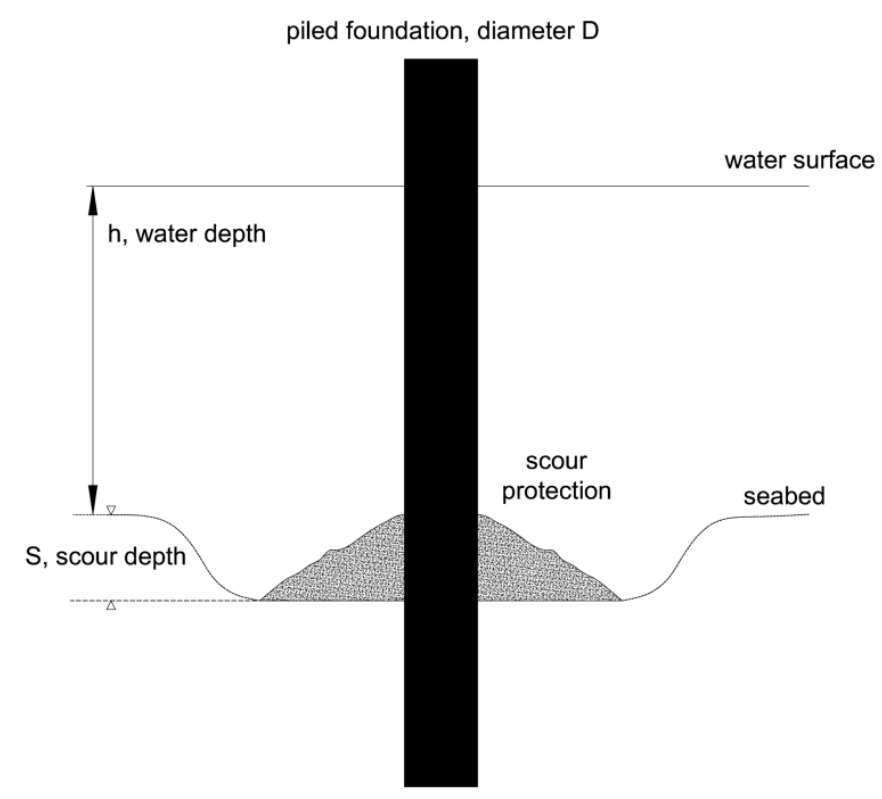

Figure 14: Secondary or edge scour definition with scour protection in place - protection laid as a mound in scour hole

The variation in scour depth with time is plotted in Figure 15. This demonstrates that the scour protection reduced the scour depths within the first 5 months of having been installed and thereafter the scour depth on average continues to increase. By the time of the November 2006 survey, the last in the present dataset, the average scour depth was still lower than the original scour depth but the range of scour depths had increased markedly (Table 4) and exceeded the original values. By this time the scour protection was having a greater effect on the seabed than the monopile alone. The location with the deepest scour in the first two surveys was the same and the deepest scour in the last three surveys were at the same location, but different from the first two. 


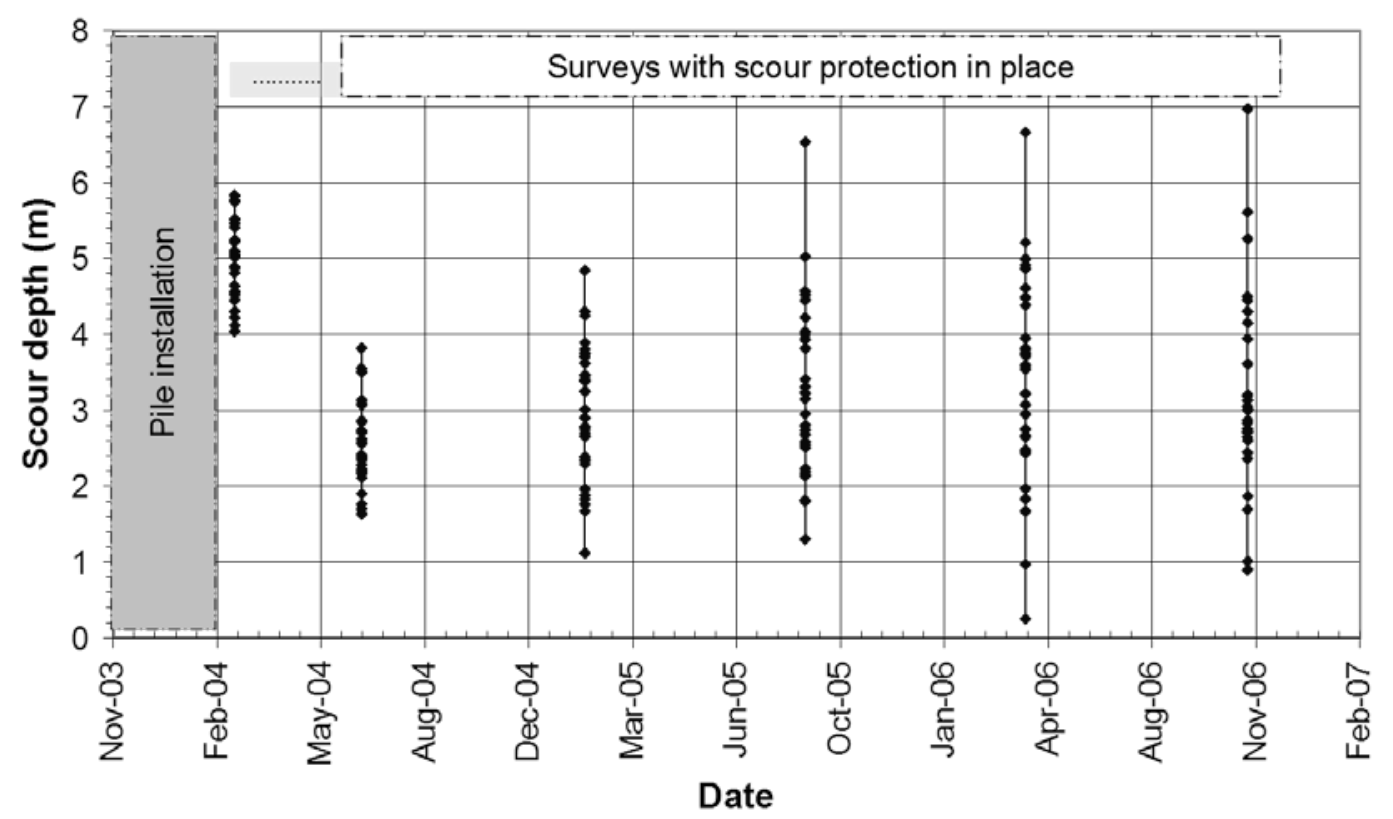

Figure 15: Time development of scour depth at Scroby Sands Wind Farm - the horizontal dashed line indicates the period scour protection was installed

Table 4: Statistics of scour at Scroby Sands

\begin{tabular}{|l|c|c|c|}
\hline & $\begin{array}{c}\text { March } \\
2004\end{array}$ & $\begin{array}{c}\text { July } \\
2004\end{array}$ & $\begin{array}{c}\text { November } \\
2006\end{array}$ \\
\hline Average scour (m) & 5.0 & 2.6 & 3.2 \\
\hline Maximum scour (m) & 5.8 & 3.8 & 7.0 \\
\hline Minimum scour (m) & 4.0 & 1.6 & 0.9 \\
\hline
\end{tabular}

\subsubsection{Arklow Bank OWF}

Rock with median weight of $200 \mathrm{~kg}$ was installed from a jackup barge around the $5 \mathrm{~m}$ diameter monopiles using a back-hoe to place rock in the scour hole that had been formed. The scour protection material at Arklow was investigated by diver survey which showed the pattern of rock placement was irregular and that in some places there were noticeable voids between placed rocks through which sand or gravel was visible as shown in Figure 16. The absence of marine fouling on the wall of the monopile indicates that the bed level is likely to have fallen, or is a sign of sediment mobility with gravel abrasion on the monopile keeping it clear. The secondary scour at Arklow was measurable in surveys but not as severe as at Scroby. 


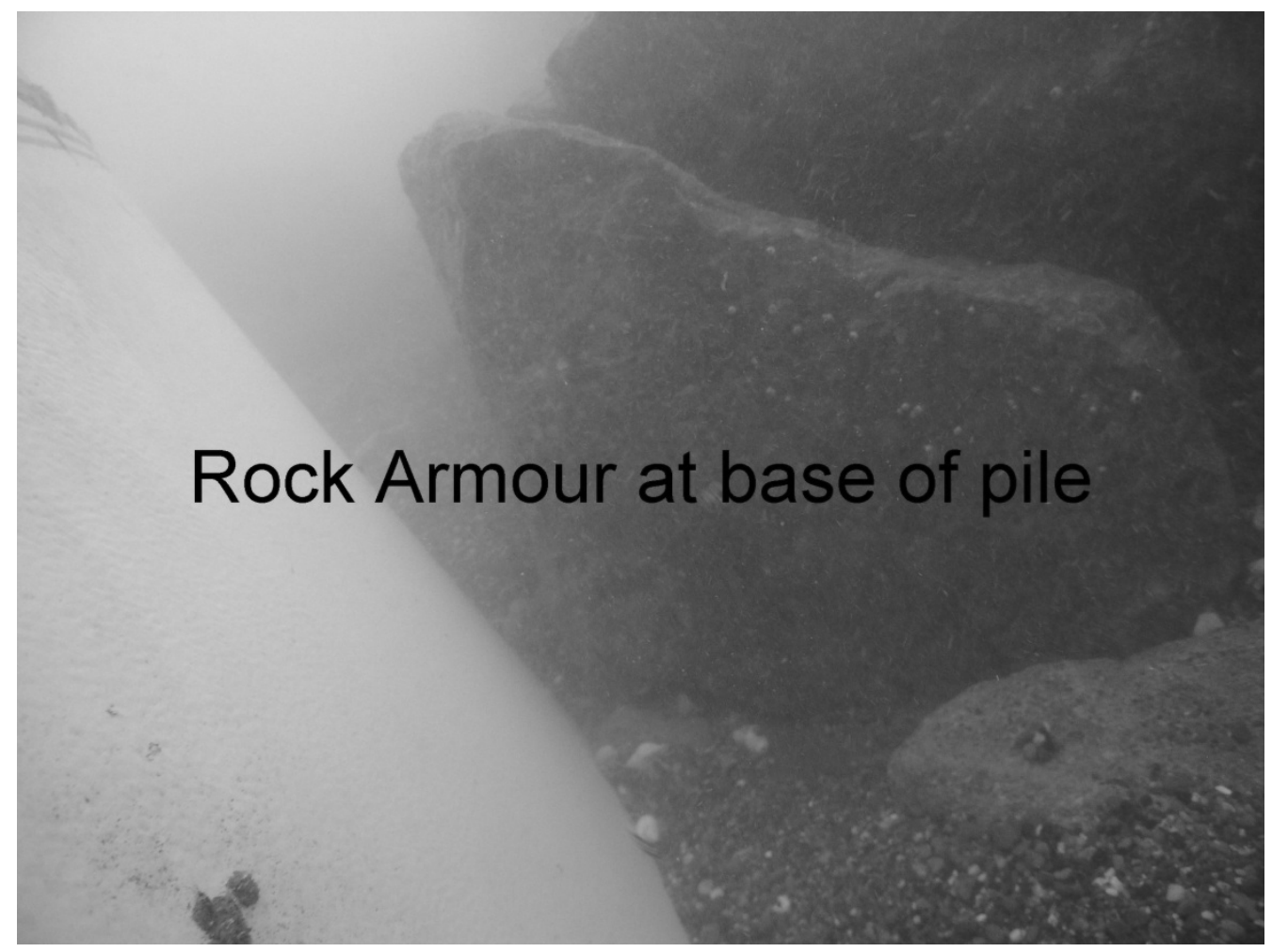

Figure 16: Rock armour at Arklow (photograph by Hydroserv)

\section{Overall assessment of scour protection results}

The scour data available with scour protection in place was collated and plotted in Figure 17 to show how the scour depths from the different sites compared. The parameters plotted are defined in Figures 13 and 14. This figure shows that the data from the different sites with characteristics in Table 1 occupy a number of clusters. The two sites where data for pre-installed scour protection (Horns Rev and Egmond) had been published are shown as a horizontal dashed line indicating the upper limit of secondary scour in a range of water depths at Horns Rev and a grey box indicating the range of scour depths reported for Egmond. The two sites for which primary data on secondary scour around the scour protection was available (Scroby Sands and Arklow Bank) have been plotted as individual datapoints. The axes on Figure 17 are compatible with those plotted in Figure 12 which enables direct comparison of the scour around the foundation with secondary scour around the edge of the scour protection. The datapoints are for the deepest level of the bed adjacent to the placed scour protection. The scour is non-dimensionalised with $D$ the pile diameter as the lengthscale even though this lengthscale has been modified by the scour protection. The envelope curve plotted on Figure 12 appears to be a useful upper limit for cases with scour protection in place and has been added to Figure 17. Whether this is a general conclusion or not is unclear since the range of projects is limited and the timescale of observations is generally less than three years. 


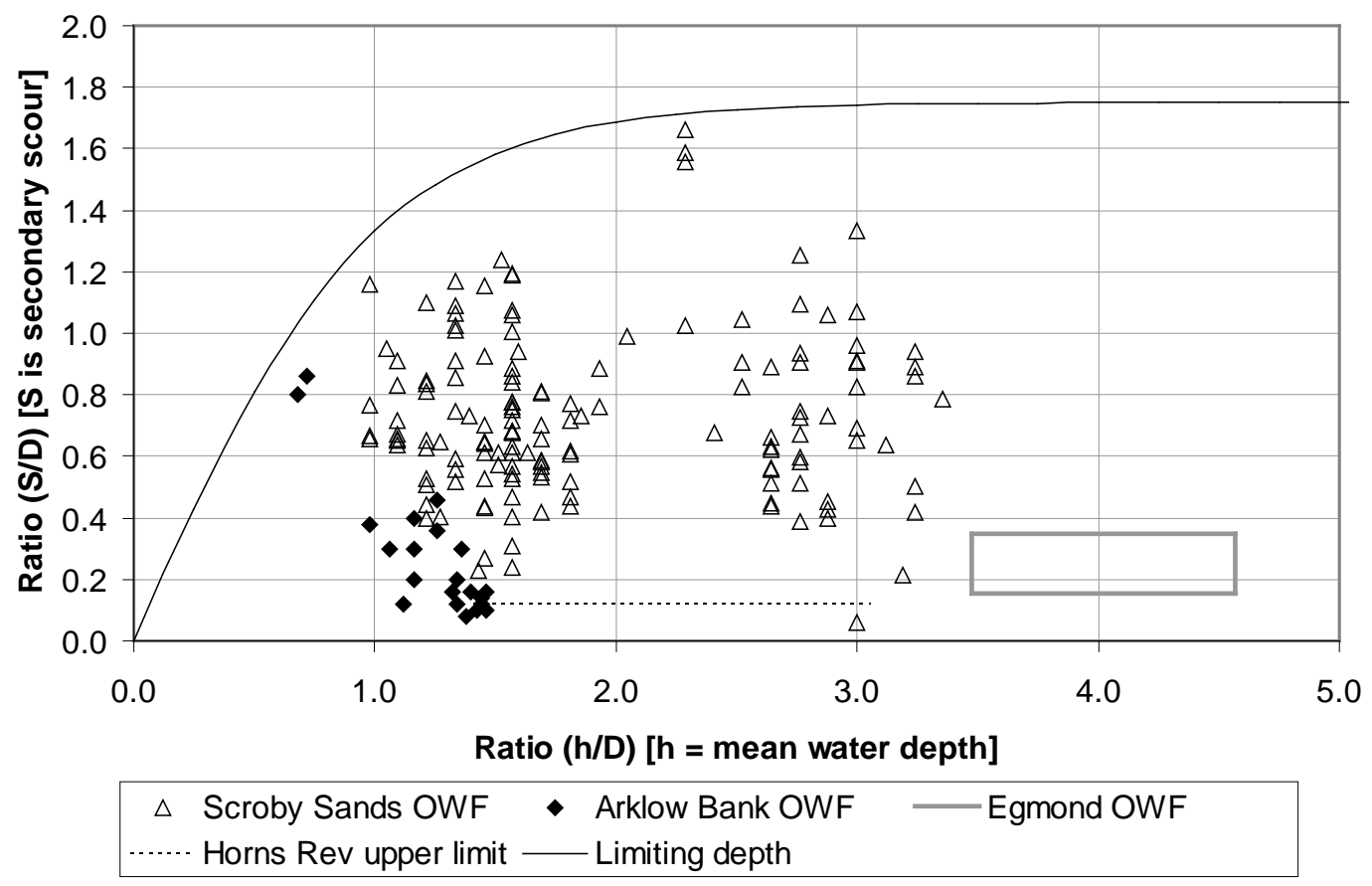

Figure 17: Relative depth of secondary scour against relative mean water depth for sites with scour protection - the grey box marked Egmond indicates the range of edge scour at that site and the dashed horizontal line for Horns Rev the upper limit for edge scour there

As with the scour data in Figure 12 the Scroby data points occupy two similar, but less distinct, clusters in terms of water depth and the range of scour depths is much greater with scour protection in place. This may be because the scour had not fully developed for the data points plotted in Figure 12 although as discussed earlier the scour development at Scroby was rapid (tidally generated). The data points for Arklow Bank lie in the lower part of the shallower depth cluster from Scroby Sands suggesting the role of the pronounced mounds of scour protection material at Scroby produce a greater disturbance on the surrounding seabed than the low height of material installed at Arklow. The impact of the engineered rock protection at Horns Rev and Egmond is similar to the lower limit of Scroby data and the lower cluster of Arklow data, which contains the scour depths recorded after two years which were in the range 0.1 to $0.38 \mathrm{D}$. The two scour depths of around 0.8D recorded at Arklow were recorded on the survey taken after one year but thereafter, until the end of the present survey database, the scour was less than this at all foundations. The difference in impact between the various sites is reflected in the suggestion of Breusers et al. (1977, p.249) that "Bad placement of riprap can provoke scour" (riprap is another name for the rock used for scour protection). Nothing is implied in the current paper by the word "bad" used in this quotation but it is clear that in a mobile sediment environment scour protection can provoke scour of the seabed away from the structure that the material is protecting. Nevertheless protection material remaining in-situ and experiencing secondary scour may well be fulfilling its primary function of preventing scour at the foundation.

The consequence of the large scour at Scroby Sands is to produce locally extensive scour holes or scour wakes (CEFAS, 2006) which contain larger amplitude bed features than the surrounding seabed. An example is shown in Figure 18. This local seabed morphology will influence the seabed habitat and species colonisation as has been analysed by Weber et al. (2004) at other sites with bedforms. 


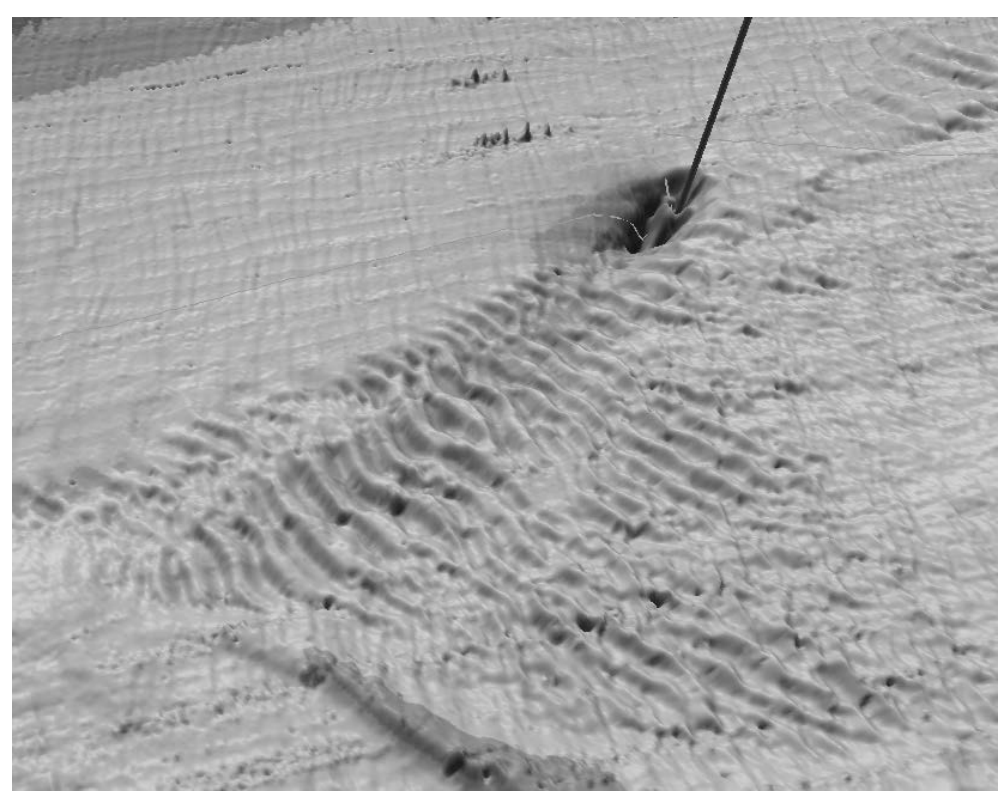

Figure 18: An example of a scour wake at Scroby Sands

Information on structures other than monopiles is required to increase the evidence base for scour since gravity base structures or multi-piled foundations may be considered for future developments of windfarms around the UK (Byrne and Houlsby, 2003). Data for secondary scour from other sites such as Thornton Bank OWF (Belgium) where large diameter gravity bases have been installed in a pre-dredged pit and backfilled with layers of scour protection was not available at the time of writing. Scour and scour protection at foundation types such as suction caissons have been investigated in the laboratory (Whitehouse, 2004 and Whitehouse, et al., 2005) but field data will be required to confirm the physical impact on the seabed.

\section{Conclusions}

The data that is available for scour around offshore windfarm (OWF) foundations, and the scour interaction with placed protection, have been collated and it has been concluded that scour is a progressive process where the seabed sediment is naturally mobile and there is an adequate thickness of that sediment for the scour to form. A range of tidal, seasonal (including storm events) and longer term variations in currents, wave action and water levels controls the way in which scour develops at a foundation. The scour sensitivity indicated by the conceptual model in Figure 1 appears to be supported by the datasets that have been analysed in the current paper. However, the datasets are limited in duration, generally up to three years, and obtained from surveys conducted at typically six monthly intervals. The variation in scour between these intervals has not been captured, although data from other structures has been presented to show that the scour varies over tidal timescales.

The following conclusions are drawn from the current study:

1. In comparison with the existing predictive formulae in guidance (DNV, 2007) and the Opti-Pile method (den Boon et al., 2004) the following conclusions can be made about scour in deep sand deposits, such as on sandbanks. DNV guidance based on laboratory data recommends that the current induced scour depth $\mathrm{S}$, in relation to the foundation diameter can be taken as $\mathrm{S} / \mathrm{D}=1.3$ (with $\pm 0.7 \mathrm{D}$ standard deviation giving an upper value of $S / D=2.0$, Sumer and Fredsøe, 2002) and the Opti-Pile method predicts the greatest scour depth that can be achieved is $S / D=1.75$. The data available to the present study 
indicates the maximum depth of scour observed at a windfarm foundation is $S / D=1.38$. This is slightly larger than the value provided in DNV guidance but it is not clear whether that value was fully developed, data was within a few months of installation, and what range of wave and current forcing had been experienced prior to the measurement being made. The largest value of scour depth observed was S/D $=1.47$ for the $1.5 \mathrm{~m}$ diameter foundation in the Otzumer Balje inlet. The overall extent of scour in a sand bed is typically 4 to 5D without placed protection.

2. The scour protection that has been placed appears to be effective in preventing bed lowering adjacent to the monopile foundations. Where material has been placed in the scour hole formed around the foundation and the top level of the protection near to or above the level of the surrounding seabed level it is evident that the mound of protection material has produced a secondary scour response. At Scroby Sands the edge scour depths are deeper than the unprotected situation and the influence of the scour wakes extends in some locations between the foundations which are 400m apart, indicating 100D extent of the scour wakes. Lower height protection structures generate a smaller secondary scour effect on the seabed although edge scour still takes place locally.

3. As more data becomes available it would be useful to undertake further evaluation of the performance of the predictions of scour in the guidance (DNV, 2004), both for scour depth and for extent at mobile sandy seabed sites. The scour extents at some of the sites, e.g. Scroby Sands, are larger than would be expected due to a simple relationship between scour depth and scour extent linked by the angle of repose of the bed sediment. This may be due to the generation of wake vortex streets downstream of the foundations and placed protection, in a tidal environment, although there is no data available to directly confirm this.

4. Where the seabed is comprised of stiff clay, there is a superficial layer of sediment overlying clay or the wave and current conditions are not generally strong enough to cause the seabed sediment to be naturally mobile, the scour will be slower or limited in depth. The role of consolidated clays in limiting scour development in the overlying sand has been demonstrated through the presently available data. However, there is uncertainty in the scour response of these clays. The erosion rate of exposed clays due to hydraulic forces, abrasion through transport of granular sediments and weathering of the exposed surface on the seabed need to be examined further to determine the controlling mechanisms and the long-term progressive scour response, e.g. over the design life of an OWF.

5. There will be reef effects on marine species within the windfarm footprint (Linley, et al., 2007). The formation of sandwaves in the scour wake, for example at Scroby Sands, will have an effect on the seabed habitat and species colonisation (Weber, et al., 2004). Changes in habitat will occur due to the direct impact of the piles themselves, and associated cabling, and the introduction of scour protection materials will directly change the substrate type. Where scour removes a veneer of sand leading to the exposure of underlying rock this will alter the habitat around each foundation.

The conclusions of the research presented in this paper and DECC (2008) have led to the identification of a number of gaps in the present state of knowledge that could be filled by additional research, either in terms of analysis of pre-existing data or through the collection of new data. Two key recommendations arising from the research were:

1. To extend the present analysis with data from more recent monitoring at the sites included in this study as well as new data from other sites. New data needs to be catalogued centrally in a consistent fashion so that future operational research can be facilitated. A comprehensive database will assist with future design and operation of offshore windfarm foundations in seabed environments of different type. More detailed information than was available in Table 1 on sedimentary environments and their properties will be required for future analysis. 
2. To carry out measurements of the time variation of scour depth and extent at OWF foundations over the period of tides, spring-neap cycles and the influence of storm events. There is evidence that the scour depth can vary both at short time scales (Harris et al., 2004; 2010) and at long timescales, even with an increase in scour depth at a sand site over a period of five years. Data will indicate how variable the scour around foundations is with and without scour protection compared with the natural seabed in similar sediments and locations.

\section{Acknowledgment}

The research on which this paper is based was funded by the UK Department for Business, Enterprise \& Regulatory Reform (BERR) (now the Department of Energy and Climate Change - DECC) through its Research Advisory Group (RAG), which facilitates a co-ordinated approach among the regulatory and funding bodies to address the key impact issues of offshore wind farms. The research was made possible through the support received from offshore wind farm developers whose data and information has been kindly shared with that project. Support for additional research and preparation of the paper came from the company research programme of HR Wallingford. The opinions, results and conclusions are those of the authors and not necessarily those of the funders nor those providing the data. The reviewers are thanked for their constructive criticism of the draft of this paper.

\section{References}

Annandale, G.W., 1995. Erodibility. Journal of Hydraulic Research, 33 (4), 471-494.

Annandale, G.W., 2006. Scour technology. Mechanics and engineering practice. Mc Graw-Hill, 368 pp.

Black, K.S. and Paterson, D M., 1997. Measurement of the erosion potential of cohesive marine sediments: A review of current in situ technology. J. Marine Env. Engg., 4, 43-83.

Breusers, H.N.C, Nicollet, G. and Shen, H.W., 1977. Local scour around cylindrical piers. J. of Hydraulic Res., IAHR, 15 (3), 211-252.

Briaud, J.-L., Ting, F.C.K., Chen, H.C., Cao, Y., Han, S.W. and Kwak, K.W., 2001. Erosion function apparatus for scour rate predictions. Journal of Geotechnical and Geoenvironmental Engineering, 127, 105113.

Byrne, B.W. and Houlsby, G.T., 2003. Foundations for Offshore Wind Turbines. Phil. Trans. Roy. Soc., 361, 2909-2930.

CEFAS, 2006. Scroby Sands Offshore Wind Farm - Coastal Processes Monitoring, Final Report AEO262 prepared for Marine Environment Division, Defra and Department of Trade and Industry, April 2006, 51 pp.

DECC, 2008. Dynamics of scour pits and scour protection - Synthesis report and recommendations (Milestones 2 and 3). Final Report prepared by HR Wallingford Ltd, ABP Marine Environmental Research Ltd and Centre for Environment, Fisheries and Aquaculture Science for the Research Advisory Group, Department of Energy and Climate Change (DECC) and Department for Environment, Food and Rural Affairs (Defra), 106 pp.

Den Boon, H., Sutherland, J., Whitehouse, R., Soulsby, R., Stam, C-J., Verhoeven, K., Høgedal, M. and Hald, T., 2004. Scour behaviour and scour protection for monopile foundations of offshore wind turbines. Proceedings of the European Wind Energy Conference, 14 pp [CD-ROM]. 
Det Norske Veritas, 2007. Design of Offshore Wind Turbine Structures, Offshore Standard DNV-OS-J101, $142 \mathrm{pp}$.

Hansen, E.A., Simonsen, H.J., Nielsen, A.W., Pedersen, J. and Høgedal, M., 2007. Scour protection around offshore wind turbine foundations, full-scale measurements. Proceedings European Offshore Wind Conference, Berlin 4-6 December 2007, Paper 159, 13 pp.

Harris, J.M., Herman, W.M. and Cooper, B.S., 2004. Offshore windfarms - an approach to scour assessment. Proceedings 2nd International Conference on Scour and Erosion, 14-17 November, Singapore, eds. Chiew, Y-M, Lim, S-Y and Cheng, N-S. Volume 1, pp. 283-291. Stallion Press.

Harris, J.M., Whitehouse, R.J.S. and Benson, T., 2010. The time evolution of scour around offshore structures. Proceedings of the Institution of Civil Engineers, Maritime Engineering, 163, March, Issue MA1, 3 -17 .

Hoffmans, G.J.C.M. and Verheij, H.J., 1997. Scour Manual, Balkema, Netherlands, 224 pp.

Høgedal, M. and Hald, T., 2005. Scour assessment and design for monopile foundations for offshore wind turbines, Proceedings Copenhagen Offshore Wind, Copenhagen, 26-28 October, 2005, 10 pp.

Jiang, J., Ganju, N.K and Mehta, A.J., 2004. Estimation of contraction scour in riverbed using SERF. Journal of Waterway, Port, Coastal, and Ocean Engineering, 130, 215-218.

Linley, E.A.S., Wilding, T.A., Black, K., Hawkins, A.J.S. and Mangi, S., 2007. Review of the reef effects of offshore wind farm structures and their potential for enhancement and mitigation. Report from PML Applications Ltd and the Scottish Association for Marine Science to the Department for Business, Enterprise and Regulatory Reform (BERR), Contract No: RFCA/005/0029P, 132 pp.

Louwersheimer, W.F., Verhagen, H.J. and Olthof, J., 2009. Scour around an offshore windturbine. Coastal Structures 2007, Proceedings of the $5^{\text {th }}$ Coastal Structures International Conference, 2-4 July 2007, Venice, Italy, eds. Franco, L., Tomasicchio, G.R. and Lamberti, A. World Scientific, 1903-1912.

Mitchener, H.J., Torfs H. and Whitehouse R.J.S., 1996. Erosion of mud sand mixtures. Coastal Engineering, Vol. 29, 1-25. [Erratum, Vol.30, (1997), 319].

Noormets, R., Ernsten, V.B., Bartholamä, A., Flemming, B. and Hebbeln, D., 2006. Local scour in a tidal environment: a case study from the Otzumer Balje tidal inlet, southern North Sea - preliminary results, Poster reproduced in report on Offshore Wind Turbines Situated in Areas with Strong Tidal Currents, Offshore Center Danmark DOC. NO. 6004RE01ER1, February 2006, Esbjerg, Denmark.

Ottesen Hansen, N-E. and Gislason, K., 2005. Movable scour protection on highly erodible sea bottom. International Coastal Symposium 2005, 5 pp.

Raaijmakers, T.C., Rudolph, D., Bergen, M.R.J. v. and Lieshout, H.v., 2007. Offshore windpark Egmond aan Zee - performance of scour protection and edge scour development. Proceedings European Offshore Wind Conference, Berlin 4-6 December 2007, 10 pp.

Rudolph, D., Bos, K.J., Luijendijk, A.P., Rietema, K. and Out, J.M.M., 2004. Scour around offshore structures - analysis of field measurements, Proceedings 2nd International Conference on Scour and Erosion, 14-17 November, Singapore, eds. Chiew, Y-M, Lim, S-Y and Cheng, N-S., Volume 1, pp. 400-407. Soulsby, R.L., 1997. Dynamics of marine sands. Thomas Telford, London, 249 pp.

Stride, A. (ed.), 1982. Offshore Tidal Sands. Chapman and Hall, 237 pp. 
Sumer, B.M. (ed.), 2006. Liquefaction around marine structures. Processes and benchmark cases. Special Issue of Journal of Waterway, Port, Coastal and Ocean Engineering, July/August 2006, 132, 4.

Sumer, B.M. and Fredsøe, J., 2002. The mechanics of scour in the marine environment. World Scientific Press, Singapore, $552 \mathrm{pp}$.

Walker, W.O., 1995. Field measurements of local pier scour in a tidal inlet. Master's Thesis, University of Florida, Department of Coastal and Oceanographic Engineering, USA, 147 pp.

Weber, A., van Dalfsen, J., Passchier, S., van der Spek, A. and van Heteren, S., 2004. Ecomorphodynamics in the North Sea seafloor and macrobenthos zonation. Marine Sandwave and River Dune Dynamics II, International Workshop, April 1-2 2004, University of Twente, The Netherlands, Proceedings Hulscher, S., Garlan, T. and Idier, D. (Eds), pp.308-313.

Whitehouse, R.J.S., 1998. Scour at Marine Structures, Thomas Telford, London, 216 pp.

Whitehouse, R.J.S., 2004. Marine scour at large foundations. In: Proceedings of the Second International Conference on Scour and Erosion, Singapore, November 2004, eds. Chiew Y-M., Lim, S-Y. and Cheng, NS., pp. 455-463. Stallion Press.

Whitehouse, R., 2006. Scour at coastal structures (Invited lecture). Proceedings Third International Conference on Scour and Erosion, November 1-3, pp.52-59, CCURNET, Gouda, The Netherlands [CDROM].

Whitehouse, R.J.S., Dunn, S.L., Alderson, J.S. and Vun, P.L., 2005. Testing of the interaction of offshore windfarm foundations with the seabed: scour and liquefaction. In: Coastal Engineering 2004. Proceedings of the 29th International Conference, Lisbon, September 2004, ed. Smith, J.M., pp. 4215-4227.

Whitehouse, R., Harris, J., Sutherland, J. and Rees, J., 2008. An assessment of field data for scour at offshore wind turbine foundations. Proceedings Fourth International Conference on Scour and Erosion, Tokyo, Japan, Paper B-13, pp. 329-335.

Whitehouse R.J.S., Soulsby R.L., Roberts W., and Mitchener H.J., 2000. Dynamics of Estuarine Muds. Thomas Telford. $210 \mathrm{pp}$.

Whitehouse, R.J.S., Sutherland, J. and O'Brien, D., 2006. Seabed scour assessment for offshore windfarm. Proceedings Third International Conference on Scour and Erosion, November 1-3, @CURNET, Gouda, The Netherlands[CD-ROM].

Williamson, H.J. and Ockenden, M.C., 1996. ISIS - An instrument for measuring erosion stress in-situ. Estuarine, Coastal and Shelf Science, Vol. 42, pp. 1-18.

Wilson, J.C. and Elliott, M., 2009. The habitat-creation potential of offshore wind farms. Wind Energy, Vol. 12, issue 2, pp. 203-212.

Winterwerp, J.C. and Van Kesteren, W.G.M., 2004. Introduction to the Physics of Cohesive Sediment in the Marine Environment. Elsevier, $479 \mathrm{pp}$. 
